\title{
The Page You Are Attempting to ACCESS has BeEN BLOCKED IN ACCORDANCE WITH NATIONAL LAWS: APPLYING A CORPORATE RESPONSIBILITY FRAMEWORK TO HUMAN RIGHTS ISSUES FACING INTERNET COMPANIES
}

\author{
By Emily C. Miletello \\ Volume XI - Spring 2011 \\ Copyright (C) Pittsburgh Journal of Technology Law and Policy
}

\begin{abstract}
According to the OpenNet Intiative, at least 40 countries engage in some degree of Internet censorship. ${ }^{1}$ While censorship may be considered justifiable for various reasons-including national security, blocking child pornography, or protecting intellectual property-some authoritative states, most notably China, censor the Internet in order to control the activities of political dissidents, international human rights groups, or those who may be otherwise critical of the government. Potentially more troubling, both authoritative nations and liberal democracies alike frequently request user-data information from Internet companies, which may infringe on individual rights to privacy and free speech, and may even lead to arbitrary detention and torture.
\end{abstract}

As the world becomes an increasingly global society, Facebook, Google, email, and other online tools are playing an unprecedented role in cheaply and instantly connecting people around the globe, creating the potential for the easy mobilization of public opinion. However, as this Article will explain, the same technology also allows for a similarly unprecedented ability for governments to track and monitor communications, often with the assistance of global Internet companies, which are often reluctant to assist. This politically explosive situation is complicated further by the fact that the duties of Internet companies to protect the human rights of their users are unclear at best, as, traditionally only states are duty holders of human rights. Indeed, although the U.N. first attempted to set human rights standards for corporations in the 1970s, very little headway has since been made despite growing global corporate influence and much academic debate on the subject.

One well-known framework for corporate responsibility, developed by Steven Ratner, sets forth a method for conservatively imposing limited human rights duties onto corporate entities in particular circumstances, depending on the nature of their operations.

This Article applies Ratner's corporate responsibility framework to Internet companies, first with respect to the censorship problem, and then with respect to the user identification problem. It also discusses whether the right to free speech can generate duties for a corporate entity, and whether the necessity of safeguarding this right should outweigh the business interests of Internet companies. Finally, this Article, recognizing the crucial role Internet companies play in regulating a uniquely important channel for speech, attempts to establish guidelines that may direct the activities of such companies as they continue to encounter human rights issues.

\footnotetext{
1 Jillian C. York, More than half a billion Internet users are being filtered worldwide, OPENNET INITIATIVE (Jan. 19, 2010), http://opennet.net/blog/2010/01/more-half-a-billion-internet-users-are-being-filtered-worldwide (last visited March 27, 2011).
} 


\title{
The Page You Are Attempting to ACCESS Has BeEN BLOCKED IN ACCORDANCE WITH NATIONAL LAWS: APPLYING A CORPORATE RESPONSIBILITY FRAMEWORK TO HUMAN RIGHTS ISSUES FACING INTERNET COMPANIES
}

\author{
By Emily C. Miletelloº \\ Volume XI - Spring 2011 \\ Copyright $(\odot$ Pittsburgh Journal of Technology Law and Policy
}

\section{TABLE OF CONTENTS}

\section{CHAPTER 1}

INTRODUCTION 1

\section{CHAPTER 2}

GLOBALIZATION AND SHIFTING OF HUMAN RIGHTS OBLIGATIONS ................................................... 5

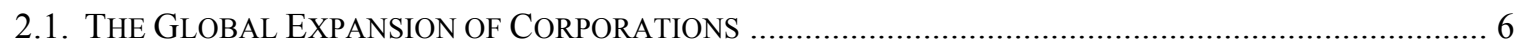

2.2. THE NEED TO IDENTIFY CORPORATIONS AS DUTY HoldERS OF HUMAN RIGHTS ......................... 8

\section{CHAPTER 3}

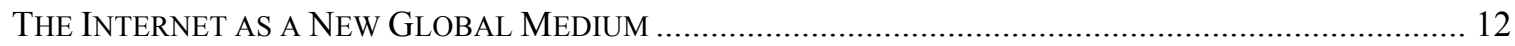

3.1. Moving the Free SPeEch Paradigm to the International StAGE …….............................. 12

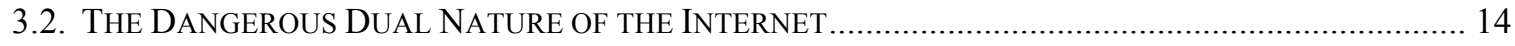

\section{CHAPTER 4}

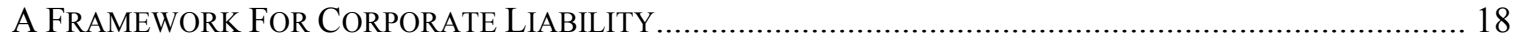

4.1. THE NeXUS BETWEen THE CORPORATION AND THE GOVERNMENT ............................................ 19

4.2. The Nexus Between the Corporation and the AfFected Population ……....................... 20

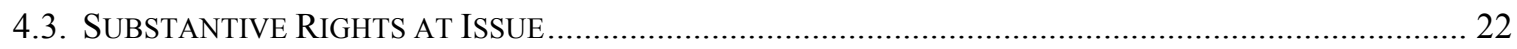

\section{CHAPTER 5}

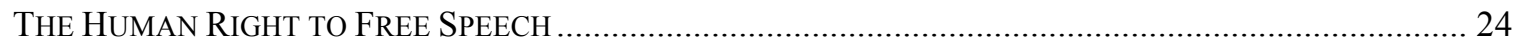

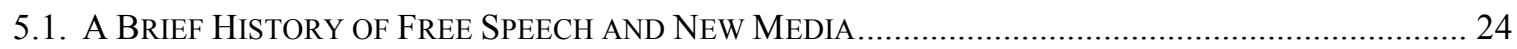

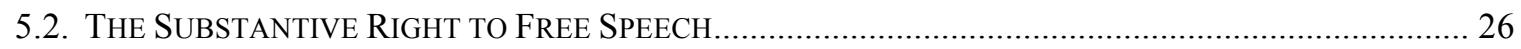

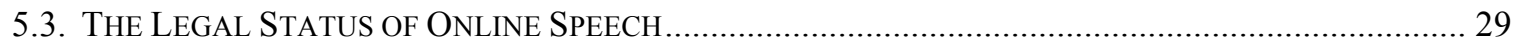

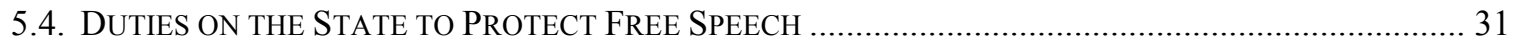

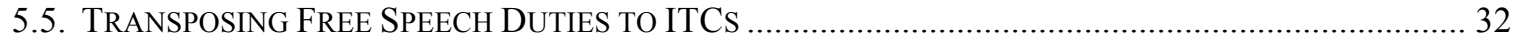

\footnotetext{
2 J.D., Villanova Law School, 2010; LLM. Public International Law, 2010, Leiden University, Leiden, The Netherlands.
} 


\section{CHAPTER 6}

APPLYING THE CONCENTRIC CIRCLES FRAMEWORK TO THE CENSORSHIP PROBLEM............................ 34

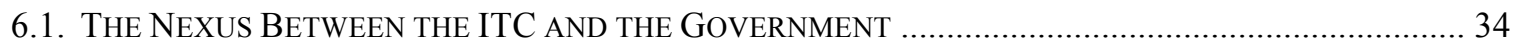

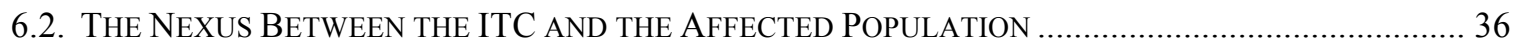

6.2.i. IDENTIFYING THE “AFFECTED POPULATION" ............................................................... 37

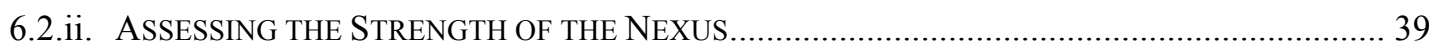

6.3. EXAMINING THE NATURE OF THE SUBSTANTIVE RIGHT AT ISSUE ................................................ 41

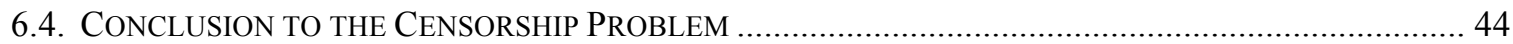

\section{CHAPTER 7}

APPLYING THE CONCENTRIC CIRCLES FRAMEWORK TO THE USER-IDENTIFICATION PROBLEM............ 47

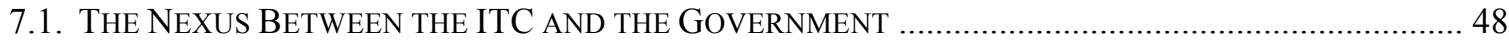

7.1.i. THE NATURE OF THE RELATIONSHIP BETWEEN ITCS AND GOVERNMENTS ......................... 49

7.1.i.(a). IDENTIFYING A UNIQUE RELATIONSHIP ........................................................... 50

7.1.i.(b). IDENTIFYING A SPECIAL DUTY IN CERTAIN NATIONS.......................................... 50

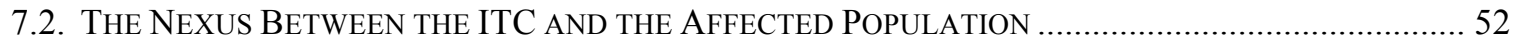

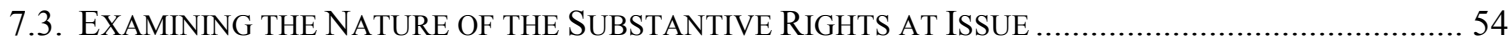

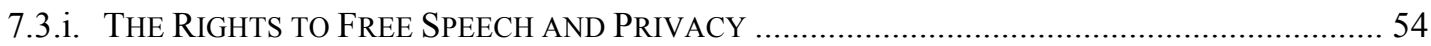

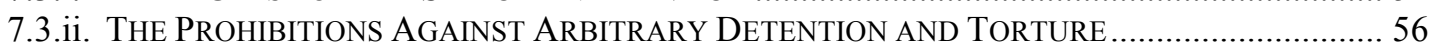

7.3.iii. BALANCING THE RIGHTS OF ITCS VS RIGHTS OF THE AFFECTED POPULATION ..................... 58

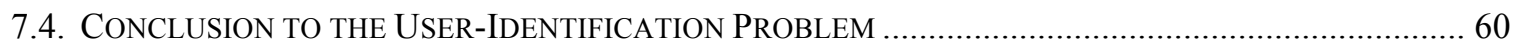

\section{CHAPTER 8}

CONCLUSION 
"And of course, the information society's very life blood is freedom. It is freedom that enables citizens everywhere to benefit from knowledge, journalists to do their essential work, and citizens to hold government accountable. Without openness, without the right to seek, receive and impart information and ideas through any media and regardless of frontiers, the information revolution will stall, and the information society we hope to build will be stillborn."

- Kofi Annan, former U.N. Secretary General ${ }^{3}$

\section{ChAPTER 1 INTRODUCTION}

China currently has more Internet users than any country in the world. ${ }^{4}$ In a marketdriven global economy, this means that business necessity is driving eager Internet companies into the lucrative Chinese market. However, by entering the Chinese market, these companies face restrictive government-mandated censorship regimes, and are often asked to respond to government requests for user information. Often, censorship policies and government requests do not align with the stated goals ${ }^{5}$ of Internet companies, and are at odds with certain human rights, like the rights to privacy and free speech. ${ }^{6}$ In some more serious cases, Internet and Telecommunication Companies ("ITCs") have provided governments with private user data used to identify, imprison, and possibly torture Internet users engaging in restricted types of speech. ${ }^{7}$ By participating in the implementation of these restrictive Internet censorship policies, Internet companies are facing scrutiny from the United Nations, certain liberal governments, and from

\footnotetext{
${ }^{3}$ Kofi Annan, Statement by H.E. Kofi Annan Secretary-General of the United Nations, WORLD SUMMIT ON THE INFORMATION SOCIETY (November 16, 2005), available at www.itu.int/wsis/tunis/statements/docs/io-unopening/1.html (last visited March 27, 2011).

${ }^{4}$ See Edward Wong, China Rebuffs Clinton on Internet Warning, N.Y. Times (January 22, 2010), available at http://www.nytimes.com/2010/01/23/world/asia/23diplo.html (last visited March 27, 2010) ("China has the most Internet users of any country, some 384 million by official count.").

${ }^{5}$ Google's well-known corporate philosophy states that "You can make money without doing evil," and "The need for information crosses all borders." Google, Corporate Information, Our Philosophy, http://www.google.com/corporate/tenthings.html (last visited March 27, 2011).

${ }^{6}$ See infra at note 14.

${ }^{7}$ See Yahoo! Inc. 's Provision of False Information to Congress, Hearing Before H. Comm. On Foreign Affairs, 110th Cong. 7 (2007) (Representative Christopher Smith stated, "based on our best information, [Shi Tao] is being tortured") (Bracket added).
} 
non-governmental organizations ("NGOs") like Human Rights Watch and Amnesty International. $^{8}$

This paper will identify and discuss an established framework for corporate social responsibility, and will then attempt to apply the framework to the two primary problems facing ITCs who do business in countries with strict censorship regimes and a history of restricting free speech and expression. As will be discussed in chapter three, these two problems require ITCs to consider human rights concerns arising from: (1) engaging in Internet censorship, and (2) government requests to divulge user information.

Imposing such a framework is challenging, as corporations are traditionally not the subjects of international law and generally not considered "duty holders" of human rights obligations. ${ }^{9}$ However, as will be demonstrated in chapter two, recent trends in international law, driven to a degree by the phenomenon of globalization, suggest progress toward a system of corporate accountability.

This paper will deal primarily with the relationship between ITCs and China, which probably has the most extensive and effective Internet filtering system in the world. ${ }^{10}$ The Chinese government has been known to seek out and punish political dissidents using the

\footnotetext{
${ }^{8}$ See e.g., Amnesty Int'l, Censorship in China, http://www.amnestyusa.org/business-and-human-rights/internetcensorship/page.do?id=1101572 (last visited March 27, 2011). Amnesty International closely follows and reports on the involvement of Internet companies in the Chinese censorship regime.

${ }^{9}$ See August Reinisch, The Changing International Legal Framework for Dealing with Non-State Actors, NoNSTATE ACTORS AND HUMAN RigHTS 37, 78-82 (2005) (stating that states are the primary, but not exclusive duty holders of human rights obligations); see also, ANDREW CLAPHAM, HUMAN RIGHTS OBLIGATIONS OF NON-STATE ACTORS 228 (2006); PrinCE OF WALES Bus. LEADERS ForUM \& AMNESTY INT’L, HUMAN RIGHTS: IS IT ANY OF YOUR BUSINESS? 83-85 (2000) ("While a company is not legally obliged under international law to comply with [human rights] standards, those companies who have violated them have found, to their cost, that society at large will condemn them."), http://iblf.org/whatwedo/responsiblebusiness/ /medai/3BCE876CCEB64249839455CA803F251B.ashx (last visited April 11, 2011).

${ }^{10}$ Officially termed the "Golden Shield Project," but nicknamed the "Great Firewall," China's censorship regime is one of the most sophisticated and extensive in the world. See, e.g. James Fallows, The Connection Has Been Reset, THE ATLANTIC, http://www.theatlantic.com/magazine/archive/2008/03/-ldquo-the-connection-has-been-resetrdquo/6650/ (last visited March 27, 2011).
} 
Internet as their forum for communication, and tellingly, China is currently imprisoning more Internet journalists than any country in the world. ${ }^{11}$

In order to demonstrate how influential and powerful ITCs have become, this paper will discuss how the Internet has become a unique platform for global communication. Consequently, ITCs, like Google, Yahoo!, and Microsoft have moved the free speech paradigm from a national to a global stage. As the Internet has increasingly become a tool for global communication, Western governments and NGOs have relied on the notion that a free and open global Internet would help to instigate progressive reform in authoritarian governments, giving individuals an open platform to coordinate and share ideas. ${ }^{12}$ However, this has not necessarily been the case. As this paper shall discuss, some nations, like China, are using the Internet as a tool to suppress speech and track political dissidents. ${ }^{13}$

Due to the dual nature of the Internet in certain countries - as a tool for free and open communication, as well as for government tracking and monitoring-ITCs have been put in a difficult human rights dilemma, which cannot easily be solved in the current state-centric international legal framework. By complying with domestic laws in nations like China, ITCs could be violating, or assisting with violations of, international human rights norms, such as the

\footnotetext{
${ }^{11}$ China currently is imprisoning 78 "netizens," Vietnam is second with only 17 imprisoned. See Reporters Without Borders, 2010: 115 Netizens Imprisoned, EN.RSF.ORG, http://en.rsf.org/press-freedom-barometer-netizensimprisoned.html?annee $=2010$ (last visited March 29, 2011).

${ }_{12}$ The Internet was even nominated for a noble peace prize. See, Ker Than, Internet Nominated for 2010 Nobel Peace Prize, MSN (Mar. 11, 2010), http://www.msnbc.msn.com/id/35823790/ (last visited March 29, 2011).

${ }^{13}$ It is not within the scope of this paper to discuss what sorts of Internet-censoring regimes are considered repressive, or what constitutes an authoritative governmental regime. However, Reporters Without Borders lists China, Burma, North Korea, Saudi Arabia, and Iran, as some of the nations with the most intensive Internetcensoring regimes. See Jan Bruck, Reporters Without Borders Warns Against Internet Censorship, DW-WORLD.DE (Dec. 3, 2010), http://www.dw-world.de/dw/article/0,5349061,00.html (last visited March 28, 2011).
} 
right to free speech, privacy, ${ }^{14}$ and, in some cases, the right to be free from arbitrary detention and torture. $^{15}$

The following chapters will attempt to expound on the human rights issues facing ITCs and the nature of the rights being violated when ITCs censor online content or divulge user information. It will then attempt to analyze these problems within an established legal framework. To this end, the following chapter will describe how globalization and trends in international law indicate a move toward greater corporate accountability in human rights law. Chapter three will briefly explain how the Internet has become a major factor in the exercise of the right to free speech, and will explain the two primary human rights dilemmas confronting ITCs operating in authoritative regimes. Chapter four will identify and explain a useful framework for gauging corporate accountability. The nature of the right to free speech as a human right will be discussed in chapter five, as well as how free speech rights translate to the Internet. Finally, chapters six and seven will apply the corporate accountability framework discussed in chapter four to the problem of censorship, and then to the user-identification problem.

\footnotetext{
${ }^{14}$ These rights can be found in international human rights instruments, including the International Covenant on Civil and Political Rights and the Universal Declaration of Human Rights. See International Covenant on Civil and Political Rights, Dec. 16, 1966, G.A. Res. 2200A (XXI), Arts. 17, 19; Universal Declaration of Human Rights, Dec. 10, 1948, G.A. Res. 217A (III), Arts. 12, 19, U.N. Doc. A/810 at 71.

${ }^{15}$ Universal Declaration of Human Rights, supra note 14, at Arts. 5, 9.
} 


\section{CHAPTER 2 \\ Globalization and SHifTing OF Human Rights Obligations}

The preamble of the Universal Declaration of Human Rights (“UDHR") states that "every individual and every organ of society, keeping this Declaration constantly in mind, shall strive by teaching and education to promote respect for these rights and freedoms and by progressive measures, national and international, to secure their universal and effective recognition and observance. . .[emphasis added]."16

In spite of this inclusive language in the UDHR, international human rights law is traditionally the province of the nation-state. International legal obligations apply primarily to states except in limited and defined circumstances. ${ }^{17}$ For example, human rights treaties, which are well-established sources of international obligations, can only be signed by states, thus only states can be held to international obligations as defined in those agreements. ${ }^{18}$ However, new types of relationships between states and corporations, marked by the proliferation of bilateral investment treaties (BIT's), and privatization, has greatly blurred the distinction between state and corporate activity. ${ }^{19}$

This chapter will discuss the phenomenon of globalization and how the development of international law has shifted international obligations onto non-state actors, specifically focusing on corporations. Although states are the primary duty holders of human rights obligations, in certain instances, international law has recognized other actors, including individuals, rebel groups and corporations, as has having human rights obligations when their acts directly impact

\footnotetext{
${ }^{16} I d$. at 9 Preamble.

${ }^{17}$ For example, in international criminal law, individuals and rebel groups have been identified as subjects of international law. See Rome Statute of the International Criminal Court, Art. 8, Sept. 28, 1998, 2187 U.N.T.S. 90.

${ }^{18}$ Vienna Convention on the Law of Treaties, art. 2(1)(a), May 23, 1969, 1155 U.N.T.S. (defines a treaty as '[an international agreement concluded between States. ..").

${ }^{19}$ See, e.g., John Ruggie, Protect, Respect and Remedy, A Framework for Business and Human rights, $139, \mathrm{UN}$ Doc. A/HRC/8/5 (Apr. 7, 2008).
} 
the ability of individuals to enjoy basic human rights. $^{20}$ The following discussion will demonstrate how international law is becoming a less state-centric legal regime, thus allowing the possibility to identify new duty holders in the area of human rights law.

To this end, this chapter will discuss theories and trends in corporate social responsibility, in order to demonstrate how the international legal community is realizing the need to impose greater legal responsibility on corporations whose business practices implicate human rights. The chapter will conclude with a brief discussion supporting the need to identify corporations as duty holders of certain human rights obligations.

\subsection{The Global EXPANSION OF CORPORATIONS}

The phenomenon of globalization has dramatically increased the power and presence of corporations around the world. More than ever, businesses affect the daily lives of people around them. Besides corporate employees, the communities in which corporations operate often depend on the economic stimulus provided by the corporation in order to maintain and operate a successful society. ${ }^{21}$ Furthermore, in modern society, it is becoming increasingly more common for private corporations to provide services traditionally offered by governments. For example, private companies are often awarded contracts to manage a community's water supply, ${ }^{22}$ and, as has been seen in Iraq, private security forces have even been employed to conduct traditional military duties. ${ }^{23}$

\footnotetext{
${ }^{20}$ For a more detailed discussion, see generally, ANDREW ClAPHAM, HUMAN RigHTS OBLIGATIONS OF NON-STATE ACTORS (2006).

${ }^{21}$ See generally, Louis Wells JR., ThiRd World MultinAtionals: The Rise of Foreign InVESTMEnt From DEVELOPING COUNTRIES (1983) (concluding that "the spread of foreign investors from developing countries is, in net, beneficial to the development process.").

${ }^{22}$ For example, Azurix Corp. was awarded a contract to manage the water supply of a small town in Argentina. When the corporation failed to adequately fulfill the contract, the case was brought before a Tribunal of the International Centre for Settlement of Investment Disputes (ICSID) in Washington, D.C. See, Azurix Corp. v. The Argentine Republic, ICSID Case No. ARB/01/12, Award (July 14, 2006) available at
} 
Furthermore, globalization means corporate expansion into different cultures and often into the developing world, in order to seek out cheap work forces and lower tax markets. In some cases, this means that the most powerful entity in a particular country may not be the government of that country, but a wealthy corporation, providing jobs, public benefits, and stimulating that nation's economy. ${ }^{24}$ The size and wealth of a particular corporation may allow that corporation to wield more authority over the people of a particular community than the national government, thus undermining the national government as the primary source of authority over the population. ${ }^{25}$

Steven Ratner and Susan Strange write about the necessity of recognizing corporations as duty holders of human rights, due to new, more connected relationships between corporations and state governments. ${ }^{26}$ According to Strange, these relationships have led to increased corporate control over the well-being of individuals, indicating a need to directly recognize corporations as duty holders of certain human rights obligations. ${ }^{27}$ Furthermore, although governments are still primarily responsible for protecting the basic rights of their citizens, they may be unwilling or unable to do so in situations where their economies are highly dependent on foreign investment. Governments may also be hesitant to impose excessive scrutiny on

http://icsid.worldbank.org/ICSID/FrontServlet?requestType=CasesRH\&actionVal=showDoc\&docId=DC507_En\&c aseId $=\mathrm{C} 5$.

${ }^{23}$ Editorial, Privatized War and Its Price, N.Y. TIMES, Jan. 11 2010, at A16, available at http://www.nytimes.com/2010/01/11/opinion/11mon1.html?_r=1.

${ }^{24}$ Steven R. Ratner, Corporations and Human Rights: A Theory of Legal Responsibility, 111 YALE L.J. 443, 459 (2001) (there is a "far denser relationship between the corporation and the host state. Instead of relying upon relatively unskilled labor to carry out mining or farming operations, the [corporation] is now an active player in the economy, hires many types of workers, and relies upon local offices to do much of its work. It is more embedded in the economy of the host state than ever before.").

${ }^{25}$ Susan Strange, The Retreat of the State: The Diffusion of Power In THE World ECONOMy 16-43 (1996) (concluding that globalization is marked by a fragmentation of authority and that economic power likely matters more than political power, thus markets are more important sources of power than states).

${ }^{26}$ See generally Ratner, supra note 24; STRANGE, supra note 25; see also, Ruggie, infra note 42, (describing the proliferation of BIT's and other agreements between states and corporations, indicating new relationships between states and businesses which could justify imposing human rights obligations on businesses).

${ }^{27}$ STRANGE, supra note 25 . 
corporations, fearing that such scrutiny might discourage businesses from investing in their economies. $^{28}$

If wealth is an indicator of power, consider the fact that in 2005, the 500 largest corporations in the world had revenues that exceeded the gross domestic product of many small countries. $^{29}$ In many cases - especially when a corporation is operating in a poor or developing country, or in a country with a history of human rights abuses - corporate activity can quickly become entangled in and indistinguishable from state activity. ${ }^{30}$ Such entanglement has led to corporate resources often being used by states to perpetuate human rights abuses. ${ }^{31}$ The most notorious modern example of this type of relationship between governments and businesses is the corporate involvement in human rights abuses in South Africa during Apartheid. ${ }^{32}$

Due to a "denser relationship between corporations and their host states,"33 power is no longer centered solely in a state's government. Ties between corporations and national governments are becoming closer, and corporate and government activities are becoming more difficult to distinguish from one another.

\subsection{The Need to Identify Corporations as Duty Holders of Human RIGHTS}

In a 1977 letter to the United States Deputy Secretary of State, Warren Christopher, United States Diplomat Steven Oxman criticized the notion that the obligations of private banks

\footnotetext{
${ }^{28}$ Ratner, supra note 24 at 462.

${ }^{29}$ Juan Pablo Bohoslavsky \& Veerle Opgenhaffen, The Past and Present of Corporate Complicit: Financing the Argentinean Dictatorship, 23 HARV. HuM RTS. J. 157, 168 (Spring 2010) (citing Janet Guyon, The Fortune Global 500, FORTUNE MAGAZINE (July 25, 2005), available at

http://money.cnn.com/magazines/fortune/fortune_archive/2005/07/25/8266629/index.htm (In 2005, all of the Fortune 500 companies had revenues that exceeded the GDP of small countries such as Jordan and Jamaica).

${ }^{30}$ Ratner, supra note 24 , at 459.

${ }^{31}$ See, e.g., Bohoslavsky \& Opgenhaffen supra note 29, at 168.

${ }^{32}$ See, e.g., Princeton N. Lyman, Paying the Price for Apartheid, N.Y. TIMES (Jan. 5, 2010), available at http://www.nytimes.com/2010/01/06/opinion/06iht-edlyman.html.

${ }^{33}$ Ratner, supra note 24 at 459.
} 
do not extend beyond their obligations to maximize profits, writing, "[b]y [this] 'rationale,' loans to Nazi Germany would have received pro forma approval so long as they were economically viable. Somewhere the line has got to be drawn." ${ }^{34}$

This statement was made over thirty years ago, but in terms of legal accountability for corporate involvement in human rights violations, no such line has been clearly drawn yet. Therefore, it is important to discuss the origins of why states were traditionally thought to be the sole duty holders of human rights obligations, and why modern realities necessitate identifying corporations as duty holders of human rights obligations in certain circumstances.

The preamble of the UDHR recognizes the inherent dignity of members of the human race as a foundation for basic rights, such as the right to liberty, ${ }^{35}$ the right to own property, ${ }^{36}$ and the right to be treated equally under the law. ${ }^{37}$ Originally, it was understood that only governments, as the primary sources of authority, had the power to protect or infringe upon these basic rights. ${ }^{38}$ Over the years, however, high profile human rights disputes involving companies like Levi Strauss and Shell, who decided to abandon their operations in Burma after becoming involved in human rights conflicts, have demonstrated that corporations are also capable of significantly affecting individuals' abilities to enjoy human rights. ${ }^{39}$

\footnotetext{
${ }^{34}$ Bohoslavsky \& Opgenhaffen, supra note 29 at 159 (citing a letter from Steven Oxman, US Diplomat, to Warren Christopher, US Deputy Sec'y of State (June 20, 1997) (handwritten notes on a copy of a memorandum from Hal F. Reynolds to A. Nachmanoff) (on file with authors).

${ }^{35}$ Universal Declaration of Human Rights, supra note 14, at Art. 3.

${ }^{36}$ Id. at Art. 17.

${ }^{37}$ Id. at Preamble, Art. 1, Art. 7.

${ }^{38}$ See Larissa van den Herik \& Jernej Letner Cernic, Regulating Corporations Under International Criminal Law, 8 J. OF INT'L CRIM. JUST. 725, 727 (2010) (“The international human rights architecture was built in the aftermath of the Second World War on the premise that individuals had to be protected from public state power.").

${ }^{39}$ See Douglass Cassel, Corporate Initiatives: A Second Human rights Revolution?, 19 FORDHAM INT'L L.J. 1963, 1971 (1996) ("Some firms have gone so far as to pull their entire operations out of countries where human rights are pervasively violated. Levi Strauss and Timberland have announced their departures from China. Furthermore, Levi Strauss, Liz Claiborne, Eddie Bauer, and Federated Department Stores, owner of Macy's, have pulled out of Burma.").
} 
Gap and Reebok, for example, have faced serious criticism for failing to provide decent working and living conditions for their factory workers in certain countries. ${ }^{40}$ These sorts of cases do not fall within human rights law generally, but are specifically encompassed in international labor law, which recognizes duties that corporations owe to their employees due to the unique employee-employer relationship. However, it seems that the theories justifying duties on corporations within the area of labor law could be expanded to protect those who are not employees of a particular corporation but are, nevertheless, closely affected by corporate activities. $^{41}$ If certain individuals have uniquely strong ties to a corporation, and their well-being is directly affected by corporate activity, then it may be reasonable that corporate duties be extended to also protect these individuals.

However, the move to extend liability to corporations under international human rights law has been met with hesitation, partly due to the fact that corporations and corporate associations have fought against the adoption of international standards to regulate their compliance with human rights norms. ${ }^{42}$ But, in spite of this lack of an international standard for liability, the reality of modern society is that corporations are expected to abide by certain human rights obligations in defined areas of law, such as international labor law, which is generally considered a subset of human rights law. ${ }^{43}$

\footnotetext{
${ }^{40}$ See Steven Greenhouse, Anti-Sweatshop Movement is Achieving Gains Overseas, N.Y. TIMES (Jan. 26, 2000), available at http://www.nytimes.com/2000/01/26/us/anti-sweatshop-movement-is-achieving-gains-overseas.html, (last visited March 28, 2011).

${ }^{41}$ See generally, VIRGINIA LEARY, The Paradox of Workers' Rights as Human Rights in HUMAN Rights, LABOR RightS AND INT'L TRADE 22 (Lance A. Compa and Steven F. Diamond, eds., 1996) (discussing labor rights as a subset of human rights).

${ }^{42}$ See John Gerard Ruggie, Business and Human rights: The Evolving International Agenda, 101 AM. J. INT’L L. 819, 823 (2007) (Ruggie describes how the International Chamber of Commerce and International Organization of Employers opposed the adoption of the Draft Norms on the Responsibilities of Transnational Corporations and Other Business Enterprises with Regard to Human Rights, even though they were strongly supported by human rights NGOs.).

${ }^{43}$ See Ratner, supra note 24, at 478-79 (explaining how duties to employees are accepted under the realm of labor law and that today, most states view labor rights as a subset of human rights).
} 
It must be noted, however, that there is still some support for the position that corporate responsibility does not extend beyond profit maximizing. ${ }^{44}$ In 1970, Nobel laureate, Milton Friedman famously wrote, "[t]here is one and only one social responsibility of business - to use its resources and engage in activities designed to increase its profits." ${ }^{\text {"45 }}$ Andrew Knox also argues that giving human rights obligations directly to private actors could actually weaken human rights protection by allowing the state to skirt its responsibilities. ${ }^{46}$ However, it seems that this has become the minority position, rather than the norm, in the international community. At the very least, it is generally recognized that corporations have a moral duty to respect human rights. ${ }^{47}$ In addressing the need to clarify this duty, Andrew Clapham and Scott Jerbi claim that the question is no longer if corporations have human rights duties, but instead, how those duties should be defined. ${ }^{48}$

In sum, because of the fragmentation of sources of authority over individuals, and because of the pervasiveness of corporate activity, there is a need to establish a framework for determining how corporate responsibility should be assessed in the field of human rights. By examining the relationships between corporations and those affected by their actions, ranging from employees to consumers to those in the community who may be indirectly affected by corporate activities, it is possible to outline potential human rights duties that may be applied to corporations when their actions implicate human rights laws.

\footnotetext{
${ }^{44}$ See e.g., Gary Becker, The Social Responsibility of Corporations, BECKER-PosNeR BloG (July 24, 2005), http://www.becker-posner-blog.com/2005/07/do-corporations-have-a-social-responsibility-beyond-stockholdervalue-becker.html (last visited March 29, 2011).

${ }^{45}$ Milton Friedman, The Social Responsibility of Business is to Increase Its Profits, N.Y. TIMES (Sept. 13, 1970), available at http://www.colorado.edu/studentgroups/libertarians/issues/friedman-soc-resp-business.html.

${ }^{46}$ See Knox, infra note 71.

${ }^{47}$ See generally Ruggie, supra note 19. (While states have a legal "duty to protect" human rights, corporations have more of a moral duty, which Ruggie refers to as the "responsibility to respect" human rights).

${ }^{48}$ Andrew Clapham \& Scott Jerbi, Categories for Complicity In Human rights Abuses, 24 HaSTINGS InT'L \& ComP. L. REV. 339, 339 (2001) ("The movement towards greater corporate social responsibility is now entering a phase where the parameters of this responsibility are being defined.").
} 


\section{Chapter 3 \\ The Internet AS A NeW Global Medium}

This chapter will discuss how the Internet has moved the free speech paradigm from a national to an international stage. It will discuss how the pervasiveness of the Internet has rendered it an important tool for social development and change, and more than merely a form of new media. Furthermore, this chapter will identify the two primary human rights issues facing ITCs: (1) censorship and (2) responding to government requests for user information. It will thereby discuss how Internet technology can be used simultaneously as a platform for speech by the masses, as well as a tool for repressive governments to persecute "cyber dissidents.",49

\subsection{Moving The Free Speech Paradigm to the International Stage}

The past twenty years have marked a telecommunications revolution greatly impacting the way the world stays connected. The Internet has brought global attention to what used to be isolated, local issues in developing countries, and has allowed interest groups and other NGOs to quickly, cheaply, and effectively mobilize public opinion. ${ }^{50}$ Furthermore, websites, message boards, and email allow any person with Internet access a platform to share their message with a global audience. Estimates differ, but in 2010, there were approximately 1.9 billion Internet users worldwide, up from just 361 million ten years ago. ${ }^{51}$ And although there is certainly not

\footnotetext{
49 "CyberDissidents use technology like blogs to organize, communicate and strengthen networks of like-minded activists." CyberDissidents.org, Who We Are, http://www.cyberdissidents.org/whoweare.html (last visited April 11, 2011).

${ }^{50}$ See e.g., Jonathan DoH \& Hildi TEEgan, Globalization AND NGOs: TRANSForming Business, GOVERNMENT AND SOCIETY 214-215 (2003) (discussing how the enhanced communicating ability of NGOs has allowed them to become more influential than ever).

${ }^{51}$ Internet World Stats, World Internet Usage Statistics, http://www.internetworldstats.com/stats.htm (last visited March 28, 2011).
} 
yet a "right" to Internet access, some societies seem to depend on the Internet to such an extent that it is beginning to be considered a quasi-public service. ${ }^{52}$

As Internet access around the world continues to grow, public debate is no longer taking place in town squares, or in limited content newspapers and magazines. Instead, public discourse has moved to free and limitless online message boards, blogs, and chat rooms. This means that ITCs like Google, Yahoo!, and Microsoft have become major enablers of global communication. These ITCs supply the forums for email exchanges, power blogs, and message boards, and allow for quick and easy searches on just about any topic imaginable.

Although many parts of the world do not have Internet access, it is important to note that the phenomenon of the Internet is not only present in Western nations. Although the percentage of China's population online is still smaller than that of nations like the United States, China currently has the most Internet users in the world, with over 338 million as of $2009 .{ }^{53}$ Furthermore, in nations without the technological capabilities to share in the "Information Age," certain organizations are making efforts to provide developing nations with Internet access. The “One Laptop Per Child" program, designed to allow children in developing African countries to have access to simple laptops with peer-to-peer wireless technology, is an example of how efforts are being made to widen the Internet user base. ${ }^{54}$ One of the program's sponsors told the

\footnotetext{
${ }^{52}$ In the United States, the Federal Communications Commission considered regulating the Internet as a public service, like electricity, gas and water. See Jeffry Bartash, Court Rejects Restrictions on Internet, MARKET WATCH (April 6, 2010), http://www.marketwatch.com/story/court-rejects-fcc-rules-on-internet-2010-04-06 (last visited March 28, 2011). See also, Public Service.co.uk, Lane Fox: “Internet Access For All,” (July 12, 2010), http://www.publicservice.co.uk/news_story.asp?id=13465 (last visited March 29, 2011).

${ }^{53}$ Owen Fletcher, China's Internet Users Outnumber U.S. Population, PCWorld (July, 16, 2009), http:/www.pcworld.com/businesscenter/article/168596/chinas internet users outnumber us population.html (last visited March 29, 2011).

${ }^{54}$ Steve Lohr, Buy a Laptop for a Child, Get Another Laptop Free, N.Y. TIMES (Sept. 24, 2007), available at http:/www.nytimes.com/2007/09/24/business/worldbusiness/24laptop.html.
} 
New York Times, “[p]art of what we're doing here is broadening the community of users, broadening the base of ideas and contributions, and that will be tremendously valuable.",55

\subsection{The Dangerous DuAl NATURE OF THE INTERNET}

"Just as steel can be used to build hospitals or machine guns, or nuclear power can either energize a city or destroy it, modern information networks and the technologies they support can be harnessed for good or for ill."

The Internet presents new speech challenges, not confronted by more traditional forms of media. Governments may use the same technology that gives voice to millions to maintain records, and to identify cyber dissidents and others who use the Internet in manners the government deems inappropriate. Although the Internet allows for unprecedented levels of participation in communication, it also gives unprecedented control to governments seeking to monitor and track communication.

In order to analyze the legal framework to apply to Internet companies who do business in countries with extensive censorship regimes, its important to identify what problems may lead to human rights violations. This paper will discuss to what extent ITCs may have duties to protect the human rights of individuals affected when ITCs: (1) engage in Internet censorship, or; (2) agree to divulge user-identifying information, when that information is likely to be used to silence or punish certain groups of speakers.

To give an example of an ITC facing the problem of censorship, Google is currently contemplating pulling its business out of China, citing its discomfort with China's strict

\footnotetext{
${ }^{55} I d$.

${ }^{56}$ Hillary Clinton, US Secretary of State, Remarks on Internet Freedom (Washington D.C., Jan. 21, 2010), available at http://www.state.gov/secretary/rm/2010/01/135519.htm.
} 
censorship regime, as well as threats from hackers. ${ }^{57}$ When Google originally launched its Chinese search engine, Google.cn, the company asserted that they believed that the benefits they could offer, in terms of presenting Chinese citizens with greater Internet access, "outweighed" their discomfort with censoring search results. ${ }^{58}$ And, until recently, Google, along with other ITCs operating in China, has complied with government-mandated censorship.

But, in a January 12, 2010 entry on the official Google blog, the company stated, "the attempts over the past year to further limit free speech on the web--have led us to conclude that we should review the feasibility of our business operations in China."59 Every ITC operating in China faces the same decision confronting Google-whether to continue its operations in the country and assist in the suppression of online speech, or abandon its business in China, thus forgoing significant potential profits and potentially leaving Chinese citizens with fewer options for Internet services.

Google further cites hackers attempting to access the e-mail accounts of human rights activists in China as one of the primary reasons for contemplating abandoning operations in China. ${ }^{60}$ In making the official Google blog entry publicly accessible, a Google spokesperson stated, "[w]e have taken the unusual step of sharing information about these attacks with a broad audience not just because of the security and human rights implications of what we have unearthed, but also because this information goes to the heart of a much bigger global debate about freedom of speech." 61

\footnotetext{
${ }^{57}$ David Drummond, A New Approach to China, The Official Google Blog (Jan. 12, 2010), http://googleblog.blogspot.com/2010/01/new-approach-to-china.html, (last visited March 28, 2011).

${ }_{58}^{58} I d$.

${ }^{59} \mathrm{Id}$.

${ }^{60} \mathrm{Id}$.

${ }^{61} I d$.
} 
In terms of the second problem - the user-identification problem - these sorts of attempts to use ITC data to track and identify human rights activists were first brought to the attention of the international community following Yahoo's! provision of user-identifying information to the Chinese government. Although most government requests for user data actually come from western nations, ${ }^{62}$ the most infamous cases, which have highlighted the dangerous capabilities of a freely available Internet in an "unfree" society, are the cases involving Yahoo! and Chinese political dissidents, posting information on a message board, Democracy Forum, using their Yahoo! accounts.

In 2003, Wang Xiaoning, an engineer in China, was arrested, charged with "incitement to subvert state power" and sentenced to ten years in prison ${ }^{63}$ after posting information on a prodemocracy message board using a personal Yahoo! email address. ${ }^{64}$ The Chinese government requested his identity from Yahoo!, who provided it, allowing him to be successfully apprehended and prosecuted. ${ }^{65}$ Yahoo! representatives claimed that they were unaware of the nature of the request and that they were simply complying with an official government order. ${ }^{66}$

A second case that received more global attention, and has only recently been settled, involved the imprisonment of Chinese journalist, Shi Tao. In 2004, Shi Tao attended a meeting of the Communist Central Propaganda Party where government officials asked journalists to refrain from writing about the upcoming anniversary of the Tiananmen Square massacre so as

\footnotetext{
${ }^{62}$ See e.g., Tom Whitehead \& James Kirkup, A Request to Snoop on the Public Every 60 Seconds, TELEGRAPH (Aug. 9, 2009), available at http://www.telegraph.co.uk/news/uknews/law-and-order/6001357/A-request-to-snoop-onpublic-every-60-seconds.html.

${ }^{63}$ See Verne Kopytoff, Yahoo Pleads for Chinese Dissidents, SAn Francisco Chronicle (Feb. 22, 2008), available at $\mathrm{http}: / /$ www.sfgate.com/cgi-bin/article.cgi?file=/c/a/2008/02/22/BU95V6LQG.DTL.

${ }^{64}$ See id.

${ }^{65}$ See id.

${ }^{66}$ Yahoo plea over China rights case, BBC NEWs (Aug, 28, 2007), available at http://news.bbc.co.uk/2/hi/6966116.stm.
} 
not to fuel any political protests or violence. ${ }^{67}$ Following the meeting, Shi Tao used his personal Yahoo! email account to send notes about the meeting to a United States based website, Democracy Forum. He was then arrested and charged with illegally providing state secrets overseas, and is currently serving ten years in prison. The Chinese government requested his user-identifying information from Yahoo!, who provided it, allowing Chinese law enforcement to identify and arrest him. ${ }^{68}$

Relatives of both men sued Yahoo! in United States courts under the Alien Torts Claims Act for the company's compliance with Chinese authorities. ${ }^{69}$ Yahoo! has settled with both families for undisclosed sums. ${ }^{70}$ However, these two instances brought the Chinese censorship regime and the corporate role in maintaining it, to the attention of the world community.

\footnotetext{
${ }^{67}$ Human Rights in China, HRIC Case Highlight: Shi Tao and Yahoo! (2005), http://www.hrichina.org/public/highlight/index.html, (last visited March 28, 2011). 


\section{Chapter 4 \\ A FRAMEWORK For CORPORATE LiabiLITY}

The subject of corporate responsibility in international law has been widely discussed in scholarly literature, and different theories for responsibility have been espoused. ${ }^{71}$ Steven Ratner's "concentric circles" theory is particularly useful in that it expands on accepted theories in international law, in areas such as labor law and environmental law, in order to conservatively extend a limited purview of human rights obligations to corporations as they continue to become more powerful global actors. Furthermore, Ratner's theory encompasses recent developments in the evolution of corporate responsibility in human rights law. For example, the 1999 United Nations ("U.N.") Global Compact calls for corporations to respect the human rights of those within their "sphere of influence." 72 Ratner builds on the idea of a corporate "sphere of influence," by attempting to identify different levels within the sphere, in order to determine what sorts of duties corporations owe to individuals based on where they fall within the sphere, with those closest to the center (the center being the corporation itself) generating the strongest human rights obligations. This chapter will explain Steven Ratner's "concentric circles" theory in order to apply it in chapters six and seven to ITCs, within the frameworks of both the censorship problem and the user-identification problem.

\footnotetext{
${ }^{71}$ See generally Ruggie, supra note 42; Ratner, supra note 24; Clapham, supra note 20. For some of the more prominent theories on corporate social responsibility see generally, John Knox, Horizontal Human Rights Law, 102 Am. J. Int'1 L. 1 (2008) (arguing that, by giving human rights obligations directly to private actors, there is a possibility of weakening human rights protection by allowing the state to skirt its responsibilities).

${ }^{72}$ United Nations Global Compact, The Ten Principles, http://www.unglobalcompact.org/aboutthegc/thetenprinciples/index.html (last visited March 29, 2011) (although the Global Compact is non-binding, it is considered soft law, thus it does warrant consideration on an international level even though it does not impose binding obligations on corporations).
} 
Ratner's "concentric circles" theory involves examining three ${ }^{73}$ relevant factors in order to establish a framework for corporate responsibility in human rights law. This theory takes into account the "diverse structures" of corporations as well as unique "modes of operating" employed by businesses in a particular country. ${ }^{74}$ These three factors, which will be further explained in turn, are: (1) the nexus between the corporation and the government, (2) the nexus between the corporation and the affected population, and (3) the substantive human rights at issue.

\subsection{The NeXus Between The CORPORATION AND GovernMENT}

Ratner begins by explaining that corporate activity can be connected to the state in a variety of ways, ranging from corporations acting as government agents, to cases where corporations are merely complicit with human rights abusing regimes. Within this category of complicity, Andrew Clapham and Scott Jerbi identify different levels of relationships between corporations and governments, ranging from beneficial or direct corporate complicity to silent corporate complicity. ${ }^{75}$ Beneficial complicity means that the corporation has knowledge that its resources are being used to further human rights abuses, and the corporation is directly benefiting from such a relationship. ${ }^{76}$ Silent complicity means that the corporation is not directly contributing to human rights abuses, but is in some way assisting with the abuses, and failing to exert its influence to attempt to stop them. ${ }^{77}$

\footnotetext{
${ }^{73}$ Ratner also writes about a fourth factor, which involves attributing an individual corporate agent's activity to the corporation in order to establish corporate accountability. As this paper deals with ITCs acting as corporate entities, this fourth factor will not be relevant for this discussion.

${ }_{75}^{74}$ Ratner, supra note 24 , at 496.

${ }^{75}$ See generally Clapham \& Jerbi, supra note 48.

${ }^{76} \mathrm{Id}$.

${ }^{77} \mathrm{Id}$.
} 
Likewise, as Ratner explains, a very close nexus between the government and the corporation, in situations described by Clapham and Jerbi as constituting beneficial corporate complicity, generate a greater obligation on the corporation to abide by human rights duties. ${ }^{78}$ According to Ratner, when a corporation is perpetrating human rights abuses at the request of the state, the corporation is acting as an arm of the state, and should be held to human rights duties very similar to those imposed on the state itself. However, as the link between the state and the corporation weakens-for example, in cases of silent complicity—-the case for justifying the imposition of human rights duties on that particular corporation also weakens. ${ }^{79}$

Ratner's first step acknowledges the fact that a corporation acting as a state agent, if left unchecked, could provide a means for governments to disregard human rights duties by "outsourcing" these duties to corporations. This step seeks to measure how closely corporate actions are tied to the government, in order to assess the appropriate level of human rights obligations to which a corporation should be held.

\subsection{The NeXus Between THE CORPORATION AND THE AFFECTED Population}

Ratner's second step is to examine the nexus between the corporation and the affected population. This requires identifying the specific groups of individuals, such as employees, customers and the surrounding population, to which the corporation may owe a duty. ${ }^{80}$ According to Ratner, this step "arises from a fundamental distinction between states and companies." ${ }^{\prime 81}$ The second step recognizes that corporate human rights obligations must be specifically defined, and significantly more limited, than those of the state. As Ratner explains,

\footnotetext{
${ }^{78}$ Ratner, supra note 24 , at 497.

${ }^{79} \mathrm{Id}$.

${ }^{80} \mathrm{Id}$. at 506.

${ }^{81} \mathrm{Id}$.
} 
states have a duty to protect the human rights of a broad spectrum of individuals, including the state's nationals and any person within the state's territory. Corporate duties, however, must be more narrowly defined, due to factors such as the territorial reach of a corporation, corporate business goals, and the nature of particular corporate activities. ${ }^{82}$ Therefore, a corporation's duties must only be owed to those with which the corporation has special ties.

Generally, individuals with the closest ties to a corporation are the employees themselves. In this step of the concentric circle theory, employees are owed the greatest duties, as they are closest to the epicenter of the sphere. Corporate duties to employees are well accepted in international law, as evidenced by standards promulgated by the International Labor Organization. ${ }^{83}$ In fact, labor law has long regulated the relationship between employers and employees on an international level. ${ }^{84}$ However, important international bodies like the UN, in the 1999 UN Global Compact, have suggested that the sphere of duty be widened beyond the employee-employer relationship. ${ }^{85}$ As is echoed by Ratner, the UN Global Compact states that corporations should protect human rights "within their sphere of influence." 86 The 2000 OECD

\footnotetext{
${ }^{82}$ Id. at 507.

${ }^{83} I d$. at 478. Ratner notes that although international labor conventions, recommendations and standards are directed primarily at states, the purpose and wording of ILO conventions make clear that they recognize duties on businesses regarding their employees). See also Convention Concerning the Application of the Principles of the Right to Organize and To Bargain Collectively, adopted 1 July 1949, Art. 1, available at http://www.ilo.org/ilolex/cgilex/convde.pl?C098 (stating that "workers shall enjoy adequate protection against acts of anti-union discrimination in respect to their employment.") Ratner asserts that this Convention imposes a duty on employers not to interfere with the ability of employees to form unions.

${ }^{84} \mathrm{Id}$. at 509. ("[International labor standards promulgated] by institutions such as the ILO suggests that governments, labor unions, and business leaders view the sphere of employer-employee relations as an appropriate target for detailed international regulation.") As noted, this target for international regulation preceded the international human rights movement by a generation.

${ }^{85}$ See United Nations Global Compact, supra note 72, ("The United Nations Global Compact is a strategic policy initiative for businesses that are committed to aligning their operations and strategies with ten universally accepted principles in the areas of human rights, labour, environment and anti-corruption.").

${ }^{86} I d$.
} 
guidelines contain a similar standard, stating that corporations should "respect human rights of those affected by their activities." ${ }^{, 87}$

As we move toward the periphery of the sphere, the duties of the corporation towards individuals with weaker corporate ties, like family members of employees, customers of the corporation, and the general community in which the corporation is operating, begin to diminish. ${ }^{88}$ And eventually, as the nexus between the corporation and the affected population becomes less and less direct, the relationship between the corporation and the population fails to generate any duty concerning the particular right at issue. ${ }^{89}$

Ratner explains how, although a corporation could owe duties to its customers, such a duty would likely not extend so far as to require that a corporation ensure that franchise owners do not sell its products in a way that could be invidiously discriminatory towards consumers. ${ }^{90}$ However, a corporation would have a duty to customers or the surrounding population if their actions directly interfered with the population's ability to enjoy a particular human right. Put another way, the more control a corporation has over a certain group's abilities to enjoy particular human rights, the stronger the corporation's obligation to protect that particular right.

\subsection{Substantive Rights At IsSue}

The third step in the concentric circles framework is to identify the substantive human right at issue. Most human rights are not absolute rights. For example, the right to free speech

\footnotetext{
${ }^{87}$ The OECD Guidelines $\S$ II.2, states that corporations should "[r]espect human rights of those affected by their activities..." Organisation for Economic Co-operation and Development, The OECD Guidelines for Multinational Enterprises (2000), available at www.oecd.org/dataoecd/56/36/192242428.pdf. See also, United Nations Global Compact, supra note 72.

${ }^{88}$ Ratner, supra note 24 , at 508.

${ }^{89} \mathrm{Id}$.

${ }^{90}$ Id. at 508-09.
} 
can be limited for reasons of national security and public morality, ${ }^{91}$ and of course the right to liberty can be limited if a person is sentenced to a prison term. Therefore it is conceivable that strong business interests may outweigh the duty on the corporation to protect a specific right.

Furthermore, certain rights, like those contained in the International Covenant on Civil and Political Rights (ICCPR), are difficult to transpose into the corporate realm. For instance, rights like the right to a fair trial, the right to marry, and the right to equal treatment under the law seemingly cannot be infringed by a corporation. By acknowledging exceptions to certain human rights in specific circumstances, and by recognizing that corporations are not capable of infringing certain rights at all, the scope of potential duties on corporations is narrowed, crucially maintaining the distinction between states and corporations as duty holders of human rights obligations.

As Ratner notes, a right does not automatically generate a corresponding duty. ${ }^{92}$ In the case of assigning corporate duties, there must be a balancing between the interests of the corporation as a business entity and the interests of the individual whose rights are affected. This balancing test helps to derive specific corporate duties, related to the specific right at issue, while maintaining the distinction between states and corporations as duty holders of human rights obligations.

\footnotetext{
${ }^{91}$ European Convention for the Protection of Human Rights and Fundamental Freedoms, art. 10.2 Sept. 3, 1953, 213 U.N.T.S. 222. ("The exercise of these freedoms, since it carries with it duties and responsibilities, may be subject to such formalities, conditions, restrictions or penalties as are prescribed by law and are necessary in a democratic society, in the interests of national security, territorial integrity or public safety, for the prevention of disorder or crime, for the protection of health or morals, for the protection of the reputation or rights of others, for preventing the disclosure of information received in confidence, or for maintaining the authority and impartiality of the judiciary.").

${ }^{92}$ Ratner, supra note 24, at 513 (citing Joseph Raz, The Morality of FreEdom 171 (1986)).
} 


\section{Chapter 5 \\ The Human Right to Free Speech}

A free and open public discourse has long been recognized as a fundamental component to a successful society, as well as a foundation for democracy. ${ }^{93}$ However, such broad participation in public discourse has never been a practical reality until the advent of the Internet.

Legal theorists have often noted that free speech is necessary to legitimize governments by allowing individuals to engage meaningfully in public discourse and voice opinions and concerns regarding their individual rights. ${ }^{94}$ This chapter will discuss the substantive rights that are included under the right to free speech and free expression. This will entail discussing how different courts have interpreted the right to free speech as a substantive right, as well as looking at the different ways in which the right to free speech and expression is codified in various human rights instruments.

This chapter will also discuss what duties a state may have to protect free speech, in order to later analyze how and if those duties should be transferred to ITCs.

\subsection{A Brief History of Free SPEeCH ANd NEW MEdiA}

Philosophers have long recognized the importance of free speech in preserving individual rights, and the value of free speech was recognized in ancient civilizations long before its status became codified in modern human rights instruments. ${ }^{95}$ But despite the long-standing recognition of free speech as an individual right, throughout history the advent of new media has

\footnotetext{
${ }^{93}$ See e.g., AleXANDER Meiklejohn, Free SPeEch And its Relation To Self Government (2004).

${ }^{94}$ See e.g., Kent Greenawalt, Free Speech Justifications, 89 CoLuM. L. REv. 119, 127 (1989) (in explaining that government accountability and the promotion of individual rights are just part of the reason to promote free speech, the author acknowledges, "No doubt holding the government to account contributes to individual human fulfillment ...").

${ }^{95}$ Kurt RaAflaub et Al., Origins of Democracy in AnCiEnt Greece 65 (2007).
} 
coincided with state attempts to regulate and suppress speech. ${ }^{96}$ As the parameters for speech have expanded, governments have feared that if these channels are left unregulated, subversive speech could quickly spread, undermining the ability of the government to function effectively, and possibly threatening the existence of the government itself. For example, when the printing press was invented and information could be reproduced and disseminated more quickly and to a wider audience than ever, a list of prohibited books was issued for the first time in history. ${ }^{97}$ Governments across Europe required that printers be licensed, so as to maintain a check on what sort of information was being printed and spread throughout communities. ${ }^{98}$

However, such government attempts at suppression of speech through new media has spawned a long history of dissent and produced much scholarly literature on the value of free speech. Philosophers like John Milton, John Locke, and John Stuart Mill helped to express why free speech is crucial to guaranteeing fundamental rights and preserving the role of the individual in society. ${ }^{99}$ Mill argues that freedom of speech and expression is essential for forward progress. Not only is it crucial to preserve individual freedoms, but it is also necessary for societies to advance in areas like law, politics, science, and technology. ${ }^{100}$

Hundreds of years later, but before the emergence of the Internet, Jurgen Habermas studied free speech and its role in the "public sphere," asserting that free speech legitimizes government and is essential to give voice to the public. ${ }^{101}$ According to Habermas, the public sphere is separate from the government, and allows a forum for individuals to discuss common

\footnotetext{
${ }^{96}$ See Ithiel de Sola Pool, Technologies of Freedom 15 (1983) (Over 800 printers and book dealers were incarcerated in the Bastille in Paris, before it was stormed in 1789).

${ }^{97}$ Id. at 14 .

${ }^{98} \mathrm{Id}$.

${ }^{99}$ The works of these particular philosophers date back to the late 17 th century, and continue until the writings of John Stuart Mill in the late 19th century. John Stuart Mill's work, On Liberty, published in 1859 is recognized as one of the first important defenses of the right to free speech. See, KAREN SANDERS, ETHICS AND JOURNALISM 66 (2003).

${ }^{100}$ See generally, JOHn StUART Mill, On LiBERTy (1859).

${ }^{101}$ J. Habermas, Between Facts and Norms: An Author's Reflections, 76 DENV. U. L. REV. 937, 942 (1988).
} 
issues and voice concerns. ${ }^{102}$ This sort of discourse is necessary to maintain a check on governmental authority in order to preserve individual rights. ${ }^{103}$ Habermas' theory is that an "ideal speech situation" should allow individuals to be free to communicate together in order to form public opinion. For this to take place there needs to be "universal access and equal participation."104 However, such an ideal speech situation was practically unimaginable until the emergence of the Internet. $^{105}$

\subsection{The Substantive Right To Free Speech}

Although it may entail different substantive rights in different cultures, the right to free speech and expression is a fundamental human right, recognized as such in most parts of the world. It is contained in many important human rights instruments, including the UDHR, which has achieved the status of customary law. ${ }^{106}$ The right to free speech or expression is also listed in the ICCPR, the European Convention on Human Rights, the American Convention on Human Rights, and the African Charter on Human and Peoples' Rights. ${ }^{107}$ Furthermore, as often noted

${ }^{102}$ Habermas defines the public sphere as, "the realm of our social life in which something approaching public opinion can be formed." J. Habermas, The Public Sphere: An Encyclopedia Article, New German Critique 3, 49 (1974).

${ }^{103}$ But see, Nancy Fraser, Rethinking the Public Sphere: A Contribution to the Critique of Actually Existing Democracy, 25/26 Social TeXT 56, 56 (1990). Fraser uses Habermas' theory as a starting point, but argues that minority voices have been marginalized within the public sphere, thus the public sphere is not as inclusive as Habermas asserts.

104 J. HABERMAS, MORAL CONSCIOUSNESS AND COMMUNICATIVE ACTION 89 (Christian Lenhardt \& Shierry Weber Nicholsen trans., 1990).

${ }^{105}$ See,e.g., A. Michael Froomkin,Habermas@Discourse.Net: Toward a Critical Theory of Cyberspace, 116 HARV. L. REV. 749 (2003).

${ }^{106}$ W. Michael Reisman, Sovereignty and Human rights in Contemporary International Law, 84 AM. J. INT’L L. 866, 867 (1990). The Universal Declaration of Human Rights described itself in 1990 as "a common standard of achievement," but is now accepted as declaratory of customary international law.

${ }^{107}$ International Covenant on Civil and Political Rights, supra note 14, at Art. 19,; European Convention for the Protection of Human Rights and Fundamental Freedoms, art. 10, Nov. 4, 1950, 213 U.N.T.S. 222; Org. of African Unity [OAU], African Charter on Human and Peoples' Rights, art. 9, OAU Doc. CAB/LEG/67/3 (Oct. 21, 1986) available at http://www1.umn.edu/humanrts/instree/z1afchar.htm; American Convention on Human Rights, art. 13, July 18, 1978, 1144 U.N.T.S. 123. 
by legal theorists, the right of free speech is closely linked with the right of self-determination and is a fundamental component in establishing democracy. ${ }^{108}$

In terms of what substantive rights fall under the realm of free speech, courts like the European Court of Human Rights, ${ }^{109}$ the United States Supreme Court, ${ }^{110}$ and the Inter-American Court of Human Rights, ${ }^{111}$ as well as legal scholars and the important human rights instruments listed above, have demonstrated that the right to free expression includes more than just a person's right to speak freely. According to philosopher John Stuart Mill, writing in 1859, freedom of speech includes three distinct rights: (1) the right to seek information and ideas, (2) the right to receive information and ideas and (3) the right to impart information and ideas [emphasis added]. ${ }^{112}$

This early description of the substantive rights that are part of the right to free speech has been reiterated, using very similar terms, in several human rights instruments. Article 10 of the European Convention on Human Rights states that, "[free] speech shall include freedom to hold opinions and to receive and impart information and ideas without interference by public authority and regardless of frontiers." ${ }^{113}$ Likewise, Article 9 of the African Charter states that, "[e]very individual has the right to receive information" and "[e]very individual shall have the

\footnotetext{
${ }^{108}$ See, A. Meiklejohn, supra note 93. (Describing how democracy is about self-governance, thus free speech is the most fundamental aspect in establishing democracy. Meiklejohn states that, "democracy will not be true to its essential ideal if those in power are able to manipulate the electorate by withholding information and stifling criticism.").

${ }^{109}$ See, e.g., Sunday Times v. UK (No. 1), 30 Eur. Ct. H.R. (ser. A) (1979) (concluding that the right of free expression is a broad right and that exceptions and restrictions to the right should be narrowly construed).

${ }^{110}$ See, e.g., Texas v. Johnson, 49 U.S. 397 (1989) (holding that the right to free speech protects more than "pure" speech, and that the burning of the American flag was protected under the First Amendment as a form of political speech).

${ }^{111}$ See e.g., Marcel Claude Reyes et al. v. Chile, Case 12.108, Report No. 60/03, Inter-Am. Ct. H.R., OEA/Ser.L/V/II.118 Doc. 70 rev. 2 at 222 (October 10, 2003), available at http://www1.umn.edu/humanrts/cases/60-03.html (noting that the right to free expression protects not only the interests of the speaker, but also the interests of those receiving the information).

${ }^{112}$ Commonwealth Secretariat, FreEdom of Expression, Assembly and Association: Best Practice 10 (2003).

${ }^{113}$ European Convention on Human Rights, art. 10.1, Nov. 4, 1950, 213 U.N.T.S. 221.
} 
right to express and disseminate his opinions within the law." ${ }^{114}$ Finally, Article 13.3 of the American Convention on Human Rights states that every person has a right to "find, receive and disseminate information."115

Courts have made it clear that unpopular or offensive speech is also guaranteed a certain level of protection. ${ }^{116}$ Within the realm of unpopular speech, the speech that should receive the most protection is political speech. ${ }^{117}$ In the European Court of Human Rights, the Court has held that the right to free speech protects all ideas and information - including speech that may "offend, shock or disturb the State." "18 The Court has also held that Article 10 of the European Convention on Human Rights, though it applies to all speech, specifically should be upheld when the speech at issue is political speech. ${ }^{119}$ In Vajnai v. Hungary, the ECHR reaffirmed that, "when freedom of expression was exercised as political speech . . . limitations were only justified if there was a clear, pressing and specific social need."120

Of course, it is important to remember that the right to free speech and expression is not an absolute right. There is room for states to regulate speech in different manners, under defined circumstances. For example, libelous or defamatory speech is punishable in most nations, and commercial speech may not be protected if it is false, or purposefully misleading to

\footnotetext{
${ }^{114}$ African Charter on Human and Peoples' Rights (“Banjul Charter”), art. 9, Jun. 27, 1981, 21 I.L.M. 58.

${ }^{115}$ American Convention on Human Rights, supra note 107, at Art. 13.3.

${ }^{116}$ See Sunday Times, supra note 109. See also Texas v. Johnson, supra note 110.

${ }^{117}$ See e.g., Johannesburg Principles on National Security, Freedom of Expression and Access to Information, UN Doc. E/CN.4/1996/39 at Principle 7(a) (1996) ("political speech critical of the government, the system of government, or even advocating for non-violent political change, may not be restricted on national security grounds.”). See also Brian Israel, "Make Money Without Doing Evil?” Caught Between Authoritarian Regulations In Emerging Markets And A Global Law of Human rights, U.S. ICTs Face A Twofold Quandry, 24 BERKELEY TECH. L.J. 617, 621 (2003).

${ }^{118}$ Handyside v. UK, 24 Eur. Ct. H.R. (ser. A) 1976.

${ }^{119}$ See, e.g., Le Pen v. France, App. No. 18788/09, 20 Eur. Ct. H.R. (2010). (Although the court here held that hate speech as such was not protected speech, it affirmed that because Mr. Le Pen was engaging in political discourse, the speech could only be banned if it was found to be pure hate speech).

${ }^{120}$ Vajnai v. Hungary, 8 Eur. Ct. H.R. (2008).
} 
consumers. $^{121}$ Furthermore, states may regulate speech based on public morality, national security, or speech meant to incite violence. ${ }^{122}$ Child pornography is blocked on the Internet in most countries for reasons of public morality, and certain sensitive information is blocked for national security purposes. ${ }^{123}$

In spite of the fact that the right to free speech is not an "absolute right," and can entail slightly different substantive rights in different cultures, the right to free speech and expression is a human right which all states have a duty to avoid infringing and to actively protect. ${ }^{124}$

\subsection{The Legal Status OF ONLINE SPEech}

As explained above, much speech and information sharing is currently occurring online. Therefore, it seems that the right to free speech and expression should also protect individuals engaging in online speech.

This sentiment was echoed by the United States Supreme Court in Reno v. ACLU, where the Court stated that the Internet is a free speech zone, and deserves as much protection as books, newspapers, and magazines. ${ }^{125}$ According to the Court, the government can no more restrict a

${ }^{121}$ See Julie C. Van Camp, Freedom of Expression at the National Endowment for the Arts (July 4, 2005) CsulB.EDU, http://www.csulb.edu/ jvancamp/freedom1.html (last visited March 29, 2011) (noting exceptions to free speech under the First Amendment of the United States Constitution).

${ }^{122} I d$.

${ }^{123}$ See United States v. The Progressive Inc., 467 F. Supp. 990, 996 (W,D. Wis. 1979) (holding that an article instructing readers how to build an "h-bomb" could be censored for national security purposes).

${ }^{124}$ See Declaration on Human Rights Defenders, G.A. Res. 53/144, Art. 2, Annex, U.N. GAOR, 53d Sess., Supp., U.N. Doc. A/RES/53/144 (1999) ("Each State has a prime responsibility and duty to protect, promote and implement all human rights and fundamental freedoms, inter alia, by adopting such steps as may be necessary to create all conditions necessary in the social, economic, political and other fields, as well as the legal guarantees required to ensure that all persons under its jurisdiction, individually and in association with others, are able to enjoy all those rights and freedoms in practice.").

${ }^{125}$ Reno v. ACLU, 521 U.S. 844, 870 (1997). 
person's access to words or images on the Internet than it could be allowed to snatch a book out of a reader's hands in the library, or cover over a nude statue in a museum. ${ }^{126}$

The Declaration Principles adopted at the World Summit on the Information Society, sponsored by the UN in 2003, also reaffirm the necessity of respecting freedom of speech online, and make clear that Article 19 of the UDHR, protecting freedom of speech, extends to online speech. ${ }^{127}$ The Principles state:

We reaffirm, as an essential foundation of the Information Society, and as outlined in Article 19 of the Universal Declaration of Human Rights, that everyone has the right to freedom of opinion and expression; that this right includes freedom to hold opinions without interference and to seek, receive and impart information and ideas through any media and regardless of frontiers. Communication is a fundamental social process, a basic human need and the foundation of all social organization. ${ }^{128}$

Furthermore, the ICCPR, to which 174 nations are signatories, states that all people "shall have the right to hold opinions without interference" and that the right of free expression "shall include freedom to seek, receive and impart information and ideas of all kinds, regardless of frontiers, either orally, in writing or in print, in the form of art, or through any other media of his choice [emphasis added]." ${ }^{\text {129 }}$ The broad language in the above mentioned human rights instruments and case law demonstrate that Internet speech should garner the same level of protection as more "traditional" forms of speech.

\footnotetext{
${ }^{126}$ Id. at 878 .

127 See Declaration of Principles, World Summit on Information the Society, Dec. 12, 2003, Doc. WSIS-

03/Geneva/Doc/4-E, at § A(4); available at http://www.itu.int/wsis/docs/geneva/official/dop.html. The Declaration Principles are non-binding, but are valuable as soft law, which the ICJ has stated as "normative" value. See, Legality of the Threat or Use of Nuclear Weapons, Advisory Opinion, ICJ Rep. 226 (1996) (The Court noted that General Assembly Resolutions, while non-binding, have "normative value," and can be useful in establishing customary law as providing evidence of opinio juris).

${ }^{128}$ Declaration of Principles, supra note 127 , at $\S \mathrm{A}(4)$.

${ }^{129}$ International Covenant on Civil and Political Rights supra note 14, at Art. 19. For a list of nations who have signed the ICCPR, see Centre for Civil and Political Rights, Status of Ratification, http://www.ccprcentre.org/en/status-of-ratification (last visited March 29, 2011).
} 


\subsection{Duties on the State to Protect Free SPeECh}

The above-mentioned human rights instruments, and their application in case law, indicate that the right to free speech in international human rights law has two important elements. First, the right to free speech protects all types of speech to varying degrees, and certain speech, like political speech, garners a higher level of protection than other types of speech, such as commercial speech. Secondly, the right to free speech protects a person's access to information, which includes the ability to give, receive, and seek information.

Therefore, as with all human rights, states have a duty to ensure that individuals can enjoy these rights. ${ }^{130}$ This means that states have a duty to ensure that certain speech is specially protected, and that individuals have access to public information. Such an obligation encompasses both a negative duty — the duty of the state to not infringe the right—as well as a positive duty - the duty of the state to enact necessary mechanisms, including legislation and enforcement, to secure the right to free speech for individuals. ${ }^{131}$

As with all human rights, states have a duty to "guarantee and protect" the right of free speech by preventing violations of the right, and by punishing infringements of the right. ${ }^{132}$ In Article 1.1 of the American Convention on Human Rights, these are referred to as "guarantee and protect obligations." ${ }^{n 33}$ Civil and political rights, like the right to free speech, are generally

\footnotetext{
${ }^{130}$ See Van Camp, supra note 121.

${ }^{131}$ See e.g., Comm. on Econ., Soc. and Cultural Rights, Gen. Cmt. No. 3 (1990), U.N. Doc. E/1991/23, Annex III, para 2( Dec. 14, 1990) (States must take 'deliberate, concrete and targeted' steps toward fulfilling human rights duties).

${ }^{132}$ For a discussion on positive and negative human rights duties, see generally, T. Buergenthal, The Normative and Institutional Evolution of International Human Rights, 19 Hum. RTS. Q. 703 (1997). See also, N. Dorsen, Civil Liberties, National Security and Human Rights Treaties: A Snapshot in Context, 3 U. C. DAVIS J. INT'L L. \& POL'Y 143, 152 (1997) ("These [human rights] treaties obligate state parties to guarantee and protect enumerated human rights ...").

${ }_{133}$ American Convention on Human Rights, art. 1.1, Nov. 22, 1969, 1144 U.N.T.S. 123. ("The States Parties to this Convention undertake to respect the rights and freedoms recognized herein and to ensure to all persons subject to their jurisdiction the free and full exercise of those rights and freedoms. ...") See also, N. Santarelli, Non-State
} 
thought to entail negative duties on states - simply the duty not to inhibit the exercise of the right - while economic and social rights impose positive obligations on the state-for example, the duty of the state to provide access to education or social security. ${ }^{134}$ However, such a distinction between positive and negative duties is largely semantic due to the fact that states have a duty to protect all human rights, including the right to free speech, through legislative and judicial processes. $^{135}$

\subsection{Transposing Free Speech Duties to ITCS}

As noted by Professor John Ruggie, "all sides agree that the state is the primary duty bearer in relation to human rights."136 Because states are the primary duty holders, duties that apply to states cannot simply be transplanted onto corporations. Whereas states have positive and negative obligations to protect the right to free speech as a human right, ITCs likely only have negative obligations. As Ratner explains, "the company's duties will typically be to avoid directly infringing upon the right; ... other derivative duties might be appropriate where the nexus between the enterprise and the individual is particularly close."137

As explained in chapter 4.3 , there must be a balancing between the corporate interest and the individual rights at stake. Furthermore, the functional differences between states and corporations must be taken into account in order to limit the scope of human rights duties imposed on a corporation. This means that the duty on ITCs should be limited to the duty to avoid actions that would interfere with an individual's ability to exercise his or her right to free

Actors Human Rights Obligations And Responsibility Under International Law, 15 REVISTA ELECTRONICA DE ESTUDIOS INTERNATIONALS (2008), available at http://www.reei.org/reei\%2015/Carrillo.pdf.

${ }^{134} I d$.

135 See supra, notes $131,133$.

${ }^{136}$ See Ruggie, supra note 42 at 828.

${ }^{137}$ Ratner, supra note 24 at 517. 
speech. It would be too much to ask, "at this stage of the international legal process, when the broad notion of business duties in the human rights area is just emerging,",138 that ITCs take proactive steps to ensure that every individual is entitled to unrestricted speech. However, it seems reasonable to impose a duty on ITCs to avoid directly infringing the right to free speech.

Based on the nature of the right to free speech, as broadly understood in national courts, and defined in international human rights instruments, ITCs' duties within the frameworks of the two problems identified in chapter three-the censorship problem and the user-identification problem-could be negative duties, as follows: ITCs have a duty to (1) refrain from actively censoring content-especially content of a political nature, and, (2) to refrain from divulging user-identifying information to authorities in nations which systematically restrict speech, except in limited circumstances.

${ }^{138}$ Id. 


\section{Chapter 6 \\ Applying The Concentric Circles Framework \\ TO THE CENSORShip PROBLEM}

In this chapter, I will apply Ratner's concentric circle framework to the ITC censorship problem, in order to gauge potential human rights liability for ITCs. This will require (1) assessing the relationship between the ITC and the governmental regime requiring censorship, (2) examining the nexus between the ITC and the population affected by censorship, and (3) examining the nature of the right at issue - in this case, the right to free speech. The following discussion will be based on the assumption that censoring online content-especially content of a political nature - is a violation of the human right to free speech as discussed above.

\subsection{THE NEXUS BETWEen THE ITC AND THE GOVERNMENT}

As demonstrated in chapter four, Ratner's framework for assessing corporate responsibility indicates that the closer the corporation's relationship with the government, the greater the corporation's human rights obligations. In other words a corporation that works closely with the government, and aligns its activities with government activities, will be held to a higher level of human rights obligations than a corporation acting independently from the government. In the case of ITCs agreeing to censor content at the request of Chinese authorities, the relationship between the corporation and the government is extremely close, thus justifying a high level of corporate responsibility.

When assessing the role of corporations in contributing to Apartheid, the Truth and Reconciliation Commission in South Africa used the same sort of analysis, examining the ties 
between corporations and human rights-abusing governments. ${ }^{139}$ The Commission established different levels for corporate involvement with the government in order to assess actions of corporations benefiting from, or actively assisting with, practices designed to maintain Apartheid. The two groups that the Commission found to be liable per se, were corporations which either "played a central role in helping to design and implement" Apartheid, or companies that "made their money by engaging directly in activities that promoted state repression." 140 Although these groups did not face legal liability at the time, it is worth noting that the Truth and Reconciliation Commission engaged in the same sort of analysis - assessing the ties between the government and the corporation-in order to determine which corporate acts were "most condemnable." $" 141$

Likewise, ITCs, by implementing the Chinese censorship regime, which requires them to censor political and religious speech, are operating under close government orders, seeking to profit from the lucrative Chinese market. By engaging in censorship, ITCs directly silence the voices of political dissidents online, and restrict open access to information, thereby interfering with individual rights to free speech.

In order to continue operating in China, ITCs must agree to censor content or face the loss of their licensing agreement, which allows them to operate in the country. ${ }^{142}$ In order to censor online content, ITCs employ staff members who actively search through blog posts and

\footnotetext{
${ }^{139}$ South Africa, Truth \& Reconciliation Comm 'n, Final Report (March 21, 2003), at Ch 2. paras. 23 et seq., available at http://www.info.gov.za/otherdocs/2003/trc. For further comparisons of Internet censorship and corporate complicity in Apartheid, see, Posting of Santiago Cueto to International Business Law Advisor, The Great Firewall of China: How Lessons from the Apartheid Area Can Lift the Information Curtain (Jan. 22, 2010), http:/www.internationalbusinesslawadvisor.com/2010/01/articles/corporate-governance-2/the-great-firewall-ofchina-how-lessons-from-the-apartheid-era-can-lift-the-information-curtain (last visited March 29, 2011).

${ }^{140}$ See, id. at ch. 2, paras. 23 - 26. See also Ratner, supra note 24, at 503.

${ }^{141} \mathrm{Id}$.

${ }^{142}$ For a detailed study on how the Chinese censorship regime operates, see, e.g., OpenNet Initiative, Internet Filtering in China in 2004-2005: A Country Study (Apr. 14, 2005), CRYPTOME.ORG, http://cryptome.org/cn/cnfilter.pdf (last visited March 29, 2011). See also Fallows, supra note 10.
} 
delete content that violates censorship laws. ${ }^{143}$ Essentially, this means that ITCs who engage in such censorship are acting as government agents, charged with carrying out a censorship regime promulgated by the government.

Thus, for this first step of the analysis, the relationship between the government and the ITC justifies the highest level of human rights obligations on the part of the ITC to respect the right to free speech. By acting under close government orders, ITCs are exercising "quasi-state authority." 144 Thus the strength of the nexus between ITCs who carry out government censorship policies satisfies the first step in justifying human rights obligations on the part of ITCs.

\subsection{The NeXus Between the ITC AND The AfFected Population}

Examining the nexus between the ITC and the affected population requires two steps. First, it is necessary to precisely define the affected population. Second, the strength of the nexus between the affected population and the ITC must be assessed. The stronger the nexus between the affected population and the ITC, the greater the human rights obligations on the ITC in terms of the identified group.

This step of the concentric circles analysis is a bit more difficult to analyze due to the fact that ITCs make their services publicly available to a global audience. Thus, the "affected population" has the potential to include hundreds of millions of users around the world. Such a

\footnotetext{
${ }^{143}$ See Rebecca MacKinnon, China's Censorship 2.0: How Companies Censor Bloggers, FIRST MondAy (Feb. 2, 2009), http://firstmonday.org/htbin/cgiwrap/bin/ojs/index.php/fm/article/view/2378/2089 (last visited March 29, 2011).

${ }^{144}$ Ratner explains that corporations acting as state agents "have duties to protect the human rights of those under their control when they exercise quasi-state authority. The extent of the duties would depend on the extent of control." Ratner, supra note 24, at 500.
} 
large affected population could become unmanageable, even for some of the most powerful global corporations. ${ }^{145}$

As mentioned in chapter four, the strongest ties between corporations and affected populations are those between employers and employees. Duties on corporations to protect employee rights have long been accepted in the area of labor law, due to the close, dependant nature of the employee-employer relationship. However, the duties on corporations become less demanding when the nexus between the corporation and the affected populace becomes weaker. For instance, when the human rights of family members of employees, customers of the corporation, and the community where the corporate offices are located, are violated due indirectly to the actions of the corporation, perhaps the nexus is too weak to justify holding the corporation to such broad human rights obligations. Therefore, it is necessary to identify a unique or special tie between the affected population and the corporation in order to justify imposing human rights obligations on the latter.

\section{2.i. IDENTIFYING THE "AFFECTED POPULATION"}

When an ITC agrees to censor content, the affected population includes hundreds of millions of individuals. Any Internet user who conducts a search and receives censored results, or whose blog is blocked for containing banned content, could be a member of the affected population. In China, this could include individuals using the Internet to share or access sexually

\footnotetext{
${ }^{145}$ As noted earlier, many argue that global corporations are better able to handle human rights obligations than certain states. "Transnational corporations have greater power than some states to affect the realization of rights, the argument continued, and "with power should come responsibility." Ruggie, supra note 42, at 824. See also Ruggie, supra note 19, at 8 (explaining the argument in favor of increased corporate responsibility).
} 
explicit, political, or religious content. ${ }^{146}$ Occasionally, social networking sites like Twitter and Facebook are also blocked, as well as the websites of certain NGOs like Amnesty International or Reporters Without Borders. ${ }^{147}$ With such a wide array of blocked content, any Internet user in a nation like China is potentially a member of the affected population.

It may be reasonable to argue that the global nature of the Internet requires that ITCs owe duties to such a global populace. After all, the "sphere of influence" of an ITC includes billions of users worldwide, so perhaps they should be held to obligations to avoid infringing the rights to free speech of Internet users across the globe. ${ }^{148}$

However, to claim that ITCs owe a duty to protect the right of free speech for each individual who uses their service seems like too heavy of a burden to place on a corporation. ${ }^{149}$ Furthermore, because each nation has different standards for what sorts of content offends public morality, or what type of speech may constitute libel or defamation, it may be practically impossible to say that ITCs owe a duty to individuals all over the world to ensure that ITC policies do not interfere with each individual's right to free speech.

Therefore, it seems necessary to more precisely define the "affected population." Due to the fact that different standards for free speech exist across the globe, the affected population should only include those individuals whose rights seem to be most clearly violated by censorship. Political speech garners the most protection on an international level, so perhaps the affected population should only include those engaging in such speech.

\footnotetext{
${ }^{146}$ See MacKinnon, supra note 143. For a detailed list of Internet content blocked in China, see also Sites Blocked in China - Highlights, HARVARD UNIVERSITY, http://cyber.law.harvard.edu/filtering/china/China-highlights.html (last visited March 29, 2011).

${ }^{147}$ Robin Wauters, China Blocks Access to Twitter, Facebook After Riots, WASH. Post, July 7, 2009, available at http:/www.washingtonpost.com/wp-dyn/content/article/2009/07/07/AR2009070701162.html.

${ }^{148}$ See Ruggie, supra note 42, at 824 ("Transnational corporations have greater power than some states to affect the realization of rights, the argument continued, and "with power should come responsibility.").

${ }^{149}$ See Ratner, supra note 24, at 517.
} 
In terms of the censorship problem, this would mean that the affected population would include individuals who use Internet services to communicate, or seek information using terms or other content banned by governments attempting to suppress political subversion. The affected population would be limited to those attempting to access banned politically-oriented websites as well as bloggers and surfers attempting to use terms like "democracy," "freedom," "human rights," and other sorts of politically sensitive words and phrases. ${ }^{150}$ By so limiting the affected population, ITCs would potentially only owe duties to individuals attempting to engage in the most protected form of speech. Such a conservative approach is necessary at this point in international law, as notions of corporate liability are still emerging. ${ }^{151}$ At the present time it would be quite difficult to argue that there is a minimum human right, which allows individuals to access sites like Facebook and Twitter, as such would place an unrealistic burden on ITCs and would create an unmanageably large "affected population."

\section{2.ii. AsSeSSING THE STRENGTH OF THE NEXUS}

If we accept that the affected population is limited to those using ITC services to share or seek out political information, then the next step is to assess the closeness of the relationship between the affected population and the ITC. The relationship in this case is a corporationcustomer relationship. According to Ratner's concentric circles framework, such a relationship does not usually generate significant human rights duties on the part of the corporation.

However, the association between the ITC and its customers who engage in political speech is a more meaningful association than that between a traditional goods-producing corporation and its customers. For example, a corporation that manufactures sunglasses

\footnotetext{
${ }^{150}$ MacKinnon, supra note 143.

${ }^{151}$ See Ratner, supra note 24, at 517.
} 
probably does not sell its goods directly to individuals. Instead, third-party retailers sell merchandise directly to customers, thereby becoming an intermediary between the corporation and the customers, and pushing the customers further to the edge of the corporation's sphere of influence. In fact, a corporation may nave no association at all with the customers once the business has relinquished its goods to a third-party retailer. It is true, of course, that ITCs, like goods-manufacturers, do not have personal relationships with their customers. However, by providing their services directly, and not through an intermediary, ITCs have much greater control than a traditional good-producing corporation, regarding how their services are presented and received.

Therefore, it seems that the nexus between ITCs and their customers is not as strong as the employee-employer nexus, but not as weak as that between "traditional" goods-producing corporations and their customers. If business-employee relationships definitely generate human rights duties, ${ }^{152}$ and business-customer relationships only generate duties in cases where there are special ties, ${ }^{153}$ then it seems likely that because ITCs provide services directly to customers, that there are, in fact, special ties between ITCs and their customers sufficient to generate at least some level of human rights duties.

Therefore, the nexus between ITCs and the affected population likely does generate a negative duty on the part of ITCs to refrain from violating the freedom of speech of the abovedefined group. A negative duty would only require that ITCs refrain from actively censoring certain content. Unlike in cases concerning corporate employees, where the nexus is strong enough to generate positive duties on the part of the corporation, the nexus in the case of

\footnotetext{
${ }^{152}$ See Ratner, supra note 24, at 478, (detailing corporate duties in the realm of Labor law).

${ }^{153} I d$. at 508. ("At a certain point, however, the nexus to the affected population fails to generate duties concerning this right-it would be difficult to conclude, for example, that the corporation has a duty to ensure that its product is sold in all parts of the country in order to ensure access for all different religious, national, or social groups.").
} 
censorship is likely not sufficient to impose positive obligations on ITCs to protect the right to free speech. ${ }^{154}$ Therefore, after ITCs have provided uncensored content, they would likely not be required to take actions to ensure that such content is freely accessible to individuals in a particular nation. ${ }^{155}$

\subsection{EXAMining THE NATURE OF THE SUbSTANTIVE Right AT ISSUE}

The third and final step of the concentric circles analysis requires analyzing the specific substantive right at issue within the censorship problem. Most crucially, this step includes a balancing test, where the interests and rights of the corporation are weighed against the affected population's interest in enjoying the particular right at issue. Within the scope of human rights, some "absolute rights," like the right to be free from torture or from arbitrary detention, ${ }^{156}$ will generate stronger duties on duty holders than other rights.

It is generally acknowledged that, like many human rights, the right to free speech is not an absolute right. Even in nations like the United States, where the right to free speech, embodied in the First Amendment of the Constitution, is considered a foundation of society, courts have widely recognized that there can be overriding governmental interests that can outweigh an individual's right to free speech. ${ }^{157}$ The ECHR has likewise concluded that, although the right to free speech is not an absolute right, restrictions on speech must further a

\footnotetext{
${ }_{154}^{15}$ See MacKinnon, supra note 143 (noting website censorship is carried out by employees of internet companies).

${ }^{155}$ But see, Molly Buetz Land, Google, China and Search, ASIL InSIGHT (Aug. 5, 2010), http://www.asil.org/files/insight100805pdf.pdf (last visited March 29, 2011) (suggesting that technological standards can be improved to make it more difficult for nations to censor Internet content. For example, if a website "increased the number of internet protocol addresses leading to its site, the site would be more difficult to block." Requiring ITCs to take such technological measures would entail a positive obligation).

${ }^{156}$ See generally T. Meron, On a Hierarchy of International Human Rights, 80 AM J. INT'L L. 1 (1986). See also Case Concerning the Barcelona Traction, Light and Power Co., Ltd., (Belgium v. Spain) 1970 I.C.J. 3 (1970) (where the Court noted that certain basic rights of the human person create erga omnes obligations).

${ }^{157}$ For an overview of the exceptions to the First Amendment see Henry Cohen, Freedom of Speech and Press: Exceptions to the First Amendment, Congressional Research Service, Oct. 16, 2009, available at http://www.fas.org/sgp/crs/misc/95-815.pdf.
} 
legitimate governmental purpose, and are to be narrowly construed. ${ }^{158}$ Thus, the rights and interests of the ITC must be balanced against the individual's right to free speech, taking into account that there are certain exceptions to the right to free speech, which could possibly be implicated when ITCs agree to censor content.

In the case of censorship of political speech, the right being infringed is the population's right to send, receive, and engage in political speech online. This is balanced against the rights and interests of the ITC. The business interest of the ITC is to maximize profits for corporate shareholders by taking advantage of the Internet markets in spite of censorship policies. Furthermore, the ITC has its own right to free speech. ${ }^{159}$ Perhaps the argument could be made that the ITC as an autonomous corporation, has ultimate control over the content available to its users. If this means that the ITC must filter content in order to take advantage of the expanding global marketplace, then the corporation's right to censor content should be considered as part of its right to free speech.

However, such an argument would fail to take into account the nature of the services provided by ITCs. For the most part, ITCs simply provide an open space for communication, and are not associated with the content posted by third parties using their services. ${ }^{160}$ Because

\footnotetext{
${ }^{158}$ See, Sunday Times, supra note 109. (The ECHR noted that exceptions to free expression shall be narrowly construed).

${ }^{159}$ See E. De Brabandere, Non-state Actors, State-Centricism and Human rights Obligations, 22 LEIDEN J. INT'L L., 191, 204 (2009) (explaining that although corporations do not, in principle, have international legal personality, thus should not have rights and duties under international law, theories for corporate responsibility generally proceed under the assumption that corporations have at least limited legal personality). See also, Posting of R. Young, Do Corporations Have Human rights?, OpenMarket.org (Sept. 10, 2009), http://www.openmarket.org/2009/09/10/docorporations-have-human-rights/ (last visited March 29, 2011) ("Corporations have the right "to sue or be sued, implead or be impleaded, grant or receive, by its corporate name, and do all other acts as persons may.") (citing W. Blackstone, COMmentaries on the LaWs of ENGLAND, Vol. 1: Of THE Rights of THE PERSON 463, (1765)); Yahoo! Inc. v. La Lingue Contre Le Racisme Et L'Antisemitisme, 433 F.3d 1199, 1217 (9th Cir. 2006) (in deciding whether or not an American court could enforce a foreign order on an American company, Yahoo!, that would curtail Yahoo's! free speech rights, the Court assumed that Yahoo!, as a corporation has a right to free speech).

${ }^{160}$ In the US, see Communication's Decency Act, 47 U.S.C. § 230 (2006) (granting immunity for Internet service providers (ISPs) based on content posted by a third party). In the EU, see Directive 2000/31/EC 8 (June, 2000) (no ISP liability for the content of third-parties if the ISP acts as a "mere conduit").
} 
ITCs generally strive to remain content-neutral, it seems like it would be difficult to argue that the free speech rights of ITCs outweigh the free speech rights of users engaging in political speech online.

Therefore, we can move forward on the assumption that the free speech rights of Internet users outweigh the free speech rights of ITCs as corporate entities. The next factor to take into account is the business interests of the corporation. If an ITC refuses to censor content in a nation like China, it could face the loss of its license to do business in the country, thus missing out on the opportunity for significant profits. Less cynically, ITCs also have an interest in broadening the user-base of the Internet. Beyond profit maximizing, an ITC may also be interested in spreading their services to parts of the world in order to allow greater participation in the information age.

The argument most often presented by ITCs facing criticism over censorship is that by operating in countries like China, users have more freedom of speech than they would if the ITC ceased to offer its services in the nation altogether. ${ }^{161}$ According to this argument, ITCs are acting in the public interest by offering their services to a nation with which will restrict the Internet regardless of the presence of that particular corporation. ${ }^{162}$ Therefore, the public interest in this scenario-having more Internet options, thereby allowing a greater portion of the population access to the Internet - may actually serve to undermine the interests of the individual when weighing the rights and interests of the ITC against the rights of the individual.

\footnotetext{
${ }^{161}$ See e.g., Steven Mufson, Even a Censored Internet Has Opened up a World For Chinese Users, WASHINGTON POST (Jan. 21 2010), available at http://www.washingtonpost.com/wpdyn/content/article/2010/01/20/AR2010012003552.html.

${ }^{162}$ But see, Human Rights and the Internet in China: Hearing Before the Congressional Human Rights Caucus, $108^{\text {th }}$ Cong. (2006) (statement of Amnesty International), available at http:/www.amnestyusa.org/document.php?id=ENGUSA20060201001 (last visited March 29, 2011) (arguing that because the Internet is already "in" China, the argument that ITCs are serving the public good by helping to "bring the Internet to China" by providing their particular services, is "outdated and unacceptable.").
} 
Therefore, the interest to be balanced on the side of the affected population is the human right "to freely seek, receive and impart information, regardless of frontiers." "163 Again, this particularly includes the right to engage in political speech. On the side of the ITC, however, we must consider the corporate interest in maximizing profit, and perhaps the collective interest of the population in having more options for access to Internet communication services, even if the service is compromised.

Unfortunately, it seems that the balancing test in the censorship problem does not yield a clear "winner." Both the individual rights and the business rights and interests seem quite strong. The right to free speech is a fundamental human right. When the speech at issue is political speech, the right to free speech is a crucial element in holding governments accountable and allowing individuals to participate in public discourse. However, keeping in mind that state obligations cannot simply be transplanted onto corporations, the interest of the ITC in engaging in censorship is also quite strong. China currently has the largest Internet market in the world. Obviously the corporate interest in profit maximizing is an influential factor on the side of the ITCs. This combined with the idea that, in the public interest, "some internet is better than no internet," 164 would seem to bring the rights and interests of the ITCs to a level that is about equal to the human rights interests of the affected population.

\subsection{Conclusion to the Censorship Problem}

In terms of the censorship problem, the balancing test in the third and final step of the concentric circle analysis does not weigh heavily in favor of either side. Therefore, in

\footnotetext{
${ }^{163}$ Universal Declaration of Human Rights, supra note 14, at Art. 19.

${ }^{164}$ See Mufson, supra note 161.
} 
determining to what extent ITCs may be identified as duty holders of the human right to free speech, the first two steps provide the most direction.

In the first step, it was shown that ITCs have very close relationships with state governments in countries with extensive censorship programs. ITCs receive lists of censored content, and then actively employ the policy as dictated by government authorities. ${ }^{165}$ Therefore, in the concentric circle analysis, the strong nexus between the government and the ITC indicates that there is a strong obligation on the ITC to respect the right to free speech of its customers.

The second step of the analysis also indicates that there should be a duty on ITCs to protect free speech. In the second step, it was shown that the nexus between the ITC and its customers, while stronger than that between a goods-producing corporation and its customers, is not as strong as the nexus between a corporation and its employees. However, within the concentric circle framework, customers of ITCs do fall relatively close to the center of the circle (the center being the ITC itself). Therefore, the unique nature of the nexus between ITCs and their customers indicates that they do have a duty to protect the rights to free speech of their users. However, such a broad obligation would seem an impractical burden to place on a nontraditional duty holder of human rights, so it is necessary to more precisely define the "affected population."

By defining the "affected population" as only those individuals who use ITC services to engage in political discourse, the right being infringed becomes more clearly defined and is less likely to be undermined by arguments emphasizing different standards regarding free speech in different parts of the world. Political speech is the most highly protected form of speech, so if the human right to free speech guarantees at least a base-level substantive right, it must guarantee the right to engage in political speech.

\footnotetext{
${ }^{165}$ See MacKinnon, supra note 143.
} 
Therefore, after this second step it seems that, based on the concentric circles framework, ITCs whose activities regarding censorship are closely linked with the state, and who have at least a moderately strong nexus with the affected population, should be identified as duty holders of the human right to free speech and must refrain from engaging in activities that infringe this right.

Taking into account all three steps of the concentric circle analysis, only the third step fails to clearly indicate the imposition of a duty on ITCs to refrain from violating the right to free speech. Therefore, based on this framework, it may not be possible to say that ITCs have a responsibility to protect the free speech of all users around the world, or that they have a positive obligation to take proactive measures to ensure their users are able to exercise their right to free speech. However, application of Ratner's concentric circles framework indicates that ITCs should be held to a negative obligation, to avoid infringing their users' rights to engage in political speech using the services provided by the ITCs. Such an obligation would likely require that ITCs refrain from actively censoring content, but would not require that ITCs ensure that the uncensored content, once provided, is freely available and accessible to Internet users in a particular nation. ${ }^{166}$

\footnotetext{
${ }^{166}$ See, e.g., Jonathan Ansfield, China Starts New Bureau to Curb Web, N.Y. TIMES (April 16, 2010), available at http://www.nytimes.com/2010/04/17/world/asia/17chinaweb.html. (China has established the "Internet News Coordination Bureau" tasked with monitoring, screening, and filtering Internet content. ITCs, would not be obligated, and likely could not be expected to take actions to combat this type of surveillance).
} 


\section{Chapter 7 \\ APPlying THE Concentric Circles Framework To THE USER-IDENTIFICATION Problem}

China currently has more imprisoned Internet journalists than any country in the world. ${ }^{167}$ According to Reporters without Borders, as of May 2010, China had seventy-six bloggers, web site creators, and "cyber dissidents" imprisoned due to their illegal uses of the Internet. ${ }^{168}$ Though this paper has mostly been focused on the human right to free speech, ITCs who respond to government requests for user-identifying information could implicate themselves in other, arguably more serious, human rights violations as well. These include the right to be free from arbitrary or prolonged detention, and even the right to be free from torture. ${ }^{169}$ The cases of Shi Tao and Wang Xiaoning, described in chapter three, indicate that ITCs can become integral actors in government efforts to silence political dissidents, by providing information used to identify and often times detain, those engaging in divisive or subversive political speech.

In this chapter, I will apply the concentric circles framework to the problem of ITCs who divulge private information to authoritative governments, in order to determine the nature of obligations on ITCs to protect human rights within the "user identification" problem. As in the previous chapter, this analysis will require (1) discussing the strength of the nexus between the ITC and the government when the government uses ITC services to identify and detain cyber dissidents, (2) examining the nexus between the ITC and the affected population, and (3) discussing the nature of the substantive human rights at issue, which includes weighing the rights and interests of the ITC against the rights of the affected population.

\footnotetext{
${ }^{167}$ See Reporters Without Borders, supra note 11.

${ }^{168}$ Id

${ }^{169}$ Universal Declaration of Human Rights, supra note 14, at Arts. 5, 9.
} 


\subsection{THE NEXUS BETWEEN THE ITC AND THE GOVERNMENT}

When an ITC complies with government requests for user-identifying information, the nexus between the government and the ITC is quite strong, although perhaps not as strong as the nexus between ITCs and the government within the framework of the censorship problem.

As noted by Ratner, "[w]here an enterprise has close ties to the government, it has prima facie a greater set of obligations in the area of human rights." ${ }^{170}$ Therefore, it is necessary to analyze the elements characterizing the relationship between ITCs who comply with government requests for user-information and the governments who use this information to engage in human rights abuses. In order to assess the nexus, this section will discuss the nature of the relationship - whether it more closely resembles an ongoing relationship between the ITC and the government, or whether there is only occasional interaction between the two actors. To further examine the strength of the nexus, I will discuss whether or not there is a unique relationship between ITCs and certain governments, which could generate particular human rights duties for ITCs. This will entail: (1) examining whether the nexus between ITCs and human rights-abusing regimes is stronger than the nexus between ITCs and liberal governments, and (2) discerning whether or not there is a special duty on ITCs who choose to operate in nations who systematically persecute cyber dissidents. Either of these two factors, if proven, would seem to strengthen the nexus between ITCs and governments of Internet-restricting countries.

\footnotetext{
${ }^{170}$ Ratner, supra note 24, at 497 (citing Costello-Roberts v. United Kingdom, 247 Eur. Ct. H.R. (Ser. A) 50, 58 (1993)) (holding that a state cannot "absolve itself from responsibility by delegating its obligations to private bodies.").
} 


\section{1.i The NATURe OF THE Relationship Between ITCS AND GOVERNMENTS}

Assuming that an ongoing relationship between ITCs and governments creates a stronger nexus than a relationship defined by only occasional interaction, then ITCs facing human rights dilemmas through the user-identification problem may be less obligated to protect human rights than ITCs facing the censorship problem. However, because governments who wish to identify cyber dissidents rely on data from ITCs, the dependant nature of the relationship may still indicate quite a strong nexus between the two actors.

In the case of censorship, state authorities give ITCs a list of terms, phrases, and names, which the government wishes to ban. ITCs are then responsible for independently carrying out this censorship program. Thus, their actions are very similar to actions of the state itself, making the nexus between the government and the ITC a very strong one. However, in the useridentification problem, ITCs are not systematically implementing a governmental policy, but are responding one-by-one to official requests as they arise. Therefore, the ties between the ITC and the government, are likely weaker than the ties between the ITC and the governments involved in censorship.

Another factor that may indicate a weaker nexus is the fact that most states with Internet capabilities issue data requests to ITCs. Government requests for user information come from all over the world — not only from states wishing to identify cyber dissidents. ${ }^{171}$ Therefore, as mentioned above, to strengthen the nexus, it would be helpful to show either (1) that the relationship between ITCs and human rights-abusing governments is somehow stronger than the relationships between ITCs and other governments, and (2) that ITCs have a greater duty to

\footnotetext{
${ }^{171}$ See Posting of M. Ingram on Wsws.org, Google Publishes Figures on Government Requests for Data, (April 26, 2010), http://www.wsws.org/articles/2010/apr2010/goog-a26.shtml (last visited March 29, 2011) (showing that the United States issued the most data requests, with the U.K. in second).
} 
analyze government requests when these requests originate from nations known to persecute cyber dissidents.

\section{1.i.(a). IDENTIFYING A UNIQUE RELATIONSHIP}

The number of data requests issued by governments around the world indicates that there is likely not a special relationship between ITCs and governments who systematically suppress free speech. Even in nations where free speech is highly protected, governments expect ITCs to provide information when requested. According to Google, in a six-month period in 2009, the United States issued 3,580 data requests to Google-more than any nation in the world. ${ }^{172}$ Therefore, it is probably not likely the relationship between, for example, Google and China, is a unique one, indicating an unusually strong nexus. In fact, looking only at the frequency of the interactions between the two actors, the nexus between ITCs and authoritative nations is likely weaker than that between ITCs and liberal democratic nations who issue far more data requests of ITCs. Although this comparison does not mean that the nexus between ITCs and nations like China is weak, it also does not serve to indicate a unique relationship or a strong nexus. Therefore, we move to the second option.

\section{1.i.(b). IDEnTIFYING A Special DUty in Certain Nations}

Corporations choosing to do business in human rights-abusing nations have generally been held to have special duties to refrain from engaging in activity that furthers these abuses. ${ }^{173}$

\footnotetext{
${ }^{172} I d$.

${ }^{173}$ See Ruggie, supra note 19, at 47-49 (discussing special corporate duties in conflict zones); See also International Organization of Employers, International Chamber of Commerce, and Business and Industry Advisory Committee to the OECD, Business and Human rights: The Role of Government in Weak Governance Zones, para. 15, (Dec. 2006), available at http://www.business-humanrights.org/Updates/Archive/SpecialRepPapers
} 
This was most notoriously recognized during and following Apartheid in South Africa, where corporations were condemned for complying with government policy meant to strengthen Apartheid. ${ }^{174}$ The Truth and Reconciliation Commission indicated that corporations should not simply comply with domestic laws in nations where human rights abuses are being perpetuated with the help of corporate activity. ${ }^{175}$ This special duty in "unfree" societies has even been recognized by ITCs themselves, who have stated that they have a duty to comply with human rights norms, even when those norms conflict with domestic law. ${ }^{176}$

Google and Yahoo! have signed a self-imposed, non-binding code of conduct—-the Global Network Initiative - indicating their pledge to "respect and protect the privacy rights of users when confronted with government demands, laws or regulations that compromise privacy in a manner inconsistent with internationally recognized laws and standards." ${ }^{177}$ The standard that emerges from this principle is that international human rights norms should outweigh domestic laws if a particular country's domestic laws do not coincide with international human rights laws. Therefore, it seems clear that there is a different, more demanding duty that applies to ITCs operating in human rights-abusing regimes. They cannot simply comply with domestic law, but must adopt policies that coincide with international human rights laws. According to this standard, ITCs have a duty to actively inquire into the nature of specific governmental requests for information, taking into account not only domestic law, but also international human rights law. ${ }^{178}$

("[C]ompanies are expected to obey the law, even if it is not enforced, and to respect the principles of relevant international instruments where national law is absent.").

${ }^{174}$ See South Africa, supra note 139, at Ch 2. paras. 23 et seq.

${ }^{175} \mathrm{Id}$.

${ }^{176}$ Global Network Initiative, Implementation Guidelines for the Principles on Freedom of Expression and Privacy, http://www.globalnetworkinitiative.org/implementationguidelines/index.php (last visited March 29, 2011).

${ }^{177} \mathrm{Id}$.

${ }^{178}$ See John Ruggie, Business and Human Rights: Further Steps Towards the Operationalization of the "protect, respect, and remedy" framework, \39, UN Doc. A/HRC/14/27, (Apr. 9, 2010). ("The appropriate corporate 
By choosing to operate in nations like China, known for systematically seeking out and persecuting cyber dissidents, ITCs have a greater duty to ensure that their services are not being used to perpetuate human rights abuses. ${ }^{179}$ Such a relationship, marked by a heightened duty, strengthens the nexus between ITCs who provide user-identifying information to governments seeking to persecute cyber dissidents.

\subsection{The NeXus Between the ITC And The AfFected Population}

Applying the concentric circles framework indicates a stronger nexus between ITCs and the affected population in terms of the user identification problem than it does when applied to the censorship problem. Due to the fact that ITCs are in possession of private user information, the link between customers and the ITC seems particularly strong. In these cases, as illustrated in chapter three, the affected population are individuals like Shi Tao and Wang Xiaoningindividuals who are subject to physical persecution by a state after ITCs provide data to state authorities, allowing them to be tracked and identified.

However, in these cases, the ITC is not directly responsible for the physical harm to the individual. The ITC likely does, however, directly violate an individual's human right to privacy, contained in article 12 of the UDHR, which then leads to actual physical persecution of that individual at the hands of the state. ${ }^{180}$ As indicated in the preamble of the Global Network Initiative, all human rights are connected and the violation of one could lead to violations of others. The preamble states:

response to managing the risks of infringing the rights of others is to exercise human rights due diligence." The requirements of due diligence differ based on the nature of the corporate activity and as well as the human rights conditions in the community where the corporation is operating).

${ }^{179} I d$.

${ }^{180}$ Universal Declaration of Human Rights, supra note 14, at Art. 12. 
All human rights are indivisible, interdependent, and interrelated: the improvement of one right facilitates advancement of the others; the deprivation of one right adversely affects others. Freedom of expression and privacy are an explicit part of this international framework of human rights and are enabling rights that facilitate the meaningful realization of other human rights." 181

ITCs provide data, which is then used by governments to perpetrate human rights abuses. Although the ITC is not directly responsible for the prolonged detention and possible torture of individuals like Shi Tao, ITCs who share user information are directly violating, at least, the right to privacy, thereby contributing to violations of other human rights like the right to be free from torture and prolonged detention.

ITCs are in control of sensitive information, such as the locations of their users, the websites they have visited and the names under which their blogs are registered. ${ }^{182}$ However, Internet users are often under the impression that their actions online are anonymous. ${ }^{183}$ Thirty years ago, a political dissident passing out flyers criticizing the government probably would not go to a third party to register their identity and whereabouts. However, unbeknownst to many Internet users, that is essentially what is happening when an individual uses blogging, email, and message board tools provided by ITCs to engage in political speech. ${ }^{184}$

User-identifying information in the possession of ITCs becomes even more sensitive when the users are living in authoritative nations and using the Internet to engage in politically subversive speech. Therefore, the nexus between the ITC and the affected population is particularly strong. Although the ITC is not directly engaging in the physical persecution of

\footnotetext{
${ }^{181}$ Global Network Initiative, supra note 174.

${ }^{182}$ See Google Privacy Center, Transparency and Choice, http://www.google.com/privacy.html (last visited March 29, 2011). See also Posting of C. Boulton on EWEEK.COM, Google Street View Accidentally Collected User Data via WiFi, (May 16, 2010), http://www.eweek.com/c/a/Search-Engines/Google-Street-View-Accidentally-ViolatesUser-Privacy-Via-WiFi-290159/ (last visited March 29, 2011).

${ }^{183}$ See e.g., M. Barbaro \& T. Zeller, A Face Is Exposed for AOL Searcher No. 441774, N.Y. TIMES (Aug. 9, 2006), available at http://www.nytimes.com/2006/08/09/technology/09aol.html?pagewanted=print.

${ }^{184}$ See Ratner, supra note 24 , at 500.
} 
cyber dissidents, it is in control of private information and has the potential to play an enormous role in the fates of individuals like Shi Tao and Wang Xiaoning.

\subsection{EXAMining THE NATURE OF THE SUbSTANTIVE Right AT ISSUE}

There are several different human rights implicated when ITCs respond to government requests for information. This section will discuss each of these rights in order to weigh the rights and interests of the ITC against the rights of the affected population. Because of the similar natures of the rights at issue as well as the similar underlying facts, the rights will be discussed in only two sections. First, the human rights of privacy and free speech will be discussed. Second, the right to be free from arbitrary prolonged detention and torture, at the hands of a state authority, will be discussed.

\section{3.i. $\quad$ The Rights to Free Speech ANd Privacy}

As briefly discussed above, ITCs who agree to share user information are likely violating an individual's right to privacy and to free expression. However, this requires first establishing that individuals have a right remain anonymous online that is part of either the right to privacy or the right to free speech. The connection between anonymity, free speech and privacy, is highlighted in the Global Network Initiative, which states that:

Privacy is a human right and guarantor of human dignity. Privacy is important to maintaining personal security, protecting identity and promoting freedom of expression in the digital age. ${ }^{185}$

Anonymity for online speakers is necessary in order to ensure that speech is not chilled. ${ }^{186}$ This is especially relevant in the case of individuals wishing to use the Internet to engage in

${ }^{185}$ Global Network Initiative, supra note 176. 
controversial speech. If they are not allowed to speak anonymously, they may choose to remain silent. $^{187}$

In the United States, the Supreme Court has repeatedly held that the right to free speech includes the right to speak anonymously. ${ }^{188}$ The Court has stated:

Protections for anonymous speech are vital to democratic discourse. Allowing dissenters to shield their identities frees them to express critical, minority views . . . Anonymity is a shield from the tyranny of the majority.... ${ }^{189}$

Beyond the purview of the Supreme Court, in a conference at the American Association for the Advancement of Science, which brought together experts from the legal community, human rights organizations, and academic institutions, it was concluded that "anonymous communication should be regarded as a strong human right."190

According to the Siracusa Principles, produced by the UN Economic and Social Council, an invasion into a person's privacy must further a legitimate aim of the state. ${ }^{191}$ Such legitimate aims include national security, public order, and public morality. ${ }^{192}$ If the problem of useridentification by ITCs is limited to cases involving "Shi Tao-types" - those who engage in

${ }^{186}$ A. Teich, et al., Anonymous Communication Policies for the Internet: Results and Recommendations of the AAAS Conference, AMERICAN ASSOCIATION FOR THE ADVANCEMENT OF SCIENCE at 11 (Jan. 27, 1999), http://www.indiana.edu/ tisj/readers/full-text/15-2\%20teich.pdf (last visited March 29, 2011) ("Banning or limiting the use of [software to maintain anonymity of users] not only produces chilling and harmful effects on freedom of speech and intrudes on privacy, according to this view, but it also opens the door to government surveillance and, in some cases, to political repression.”).

${ }^{187} I d$.

${ }^{188}$ McIntyre v. Ohio Elections Comm., 514 U.S. 334 (1995).

${ }^{189}$ Id. See also Electronic Frontier Foundation, Cases Related to Anonymity, http://www.eff.org/related/3005/case (last visited March 29, 2011).

${ }^{190}$ See A. Teich, et al., supra note 186 , at 7.

${ }^{191}$ U.N. Econ. and Soc. Council [ECOSOC], Sub-Comm'n on the Prevention of Discrimination and Prot. of Minorities, Siracusa Principles on the Limitation and Derogation of Provisions in the International Covenant on Civil and Political Rights, UN Doc. E/CN.4/1984/4 (Sept. 28, 1984), available at http://graduateinstitute.ch/faculty/clapham/hrdoc/docs/siracusa.html. ("National Security may be invoked to justify measures limiting certain rights only when they are taken to protect the existence of the nation or its territorial integrity or political independence against force or threat of force. . . national security may only be invoked to restrict privacy and expression when accompanied by sufficient procedural safeguards and remedies to guard against abuse.").

${ }^{192}$ Id. See also European Convention for the Protection of Human Rights and Fundamental Freedoms, arts. 10(2), 8(2), Nov. 4, 1950, 213 U.N.T.S. 222 (interference with these rights on as "necessary in a democratic society ...."). 
political speech using ITC services - then by agreeing to share identifying information with nations like China, the ITC has violated the right to privacy and free expression of the Internet user. Because the government has no legitimate aim in identifying the individual, other than to quell controversial speech or possibly detain him for engaging in such speech, then international human rights law would seem to require that the ITC should refuse to share the information with the government.

Anonymous communication is a protected human right, encompassed in the right to privacy, as well constituting a component of the right to free speech. When ITCs provide governments with identifying information of cyber dissidents, they are infringing an individual's right to privacy and to free expression, which in turn could lead to more serious human rights abuses.

\section{3.ii. The Prohibitions Against Arbitrary Detention AND TORTURE}

As previously discussed, state governments wishing to punish cyber dissidents have been known to detain and even torture individuals engaging in prohibited communication. While these violations are evidently not occurring at the hands of ITCs themselves, but rather at the hands of certain states, they are often enabled by ITCs through the provision of information.

The ECHR has held that if a state extradites an individual to a nation where there is a "real risk" that that individual will be subject to inhumane and degrading treatment, the extraditing state could be responsible for the violations of these rights by the third-party state. ${ }^{193}$ Employing this reasoning by analogy, if there is a "real risk" that an individual like Shi Tao

\footnotetext{
${ }^{193}$ Soering v. UK (No. 161), 11 Eur. Ct. H.R. 439 (ser. A) (1989) (The Court held that if there was a "real risk" that by extraditing an individual, he could be subject to inhuman or degrading treatment, then the extraditing nation could be responsible for a breach of the individual's human rights).
} 
could be subject to torture after an ITC shares his identifying information, then perhaps that corporation too could be held responsible for human rights violations ultimately carried out by the state.

Although this "real risk" criteria may be difficult to transpose onto corporations as nontraditional duty holders of human rights obligations, it could be useful in cases where an ITC complies with government requests which they know, or have reason to believe, will lead to the detention and torture of an individual. ${ }^{194}$ However, such a level of knowledge would be very difficult to prove unless the state and the ITC were working very closely together. If a high level of knowledge could be established on the part of the ITC, then the individual interests would weigh much more heavily, as it may be possible to qualify the violation of the individual's right to be free from arbitrary detention and torture as a direct violation of these rights by the ITC. This would bring the individual interests much closer to the center of the concentric circle framework, and would certainly generate a stronger duty on the ITC. However, in most cases, such closeness would be unusual—or, in any event, difficult to establish—so it seems more likely that the ITC would be only indirectly interfering with an individual's rights to be free from torture or arbitrary detention.

Therefore, to go back to the concentric circles framework, these particular human rights, though serious due to their status as absolute rights, are not as closely linked to the ITC itself as the substantive rights of free speech and privacy. Although it is feasible that, in certain circumstances, a high level of intent and knowledge could transform these violations into direct

\footnotetext{
${ }^{194}$ See Ruggie, supra note 178, at 1 1. (The corporate responsibility to respect human rights includes a requirement "to act with due diligence to avoid infringing on the rights of others." Due diligence could require that ITCs examine government requests in order to determine if complying with the request could lead to serious human rights violations).
} 
violations of the rights to be free from torture and arbitrary detention, such a scenario is unlikely and would be difficult to prove.

There are competing factors at issue in terms of assessing the substantive rights implicated in the user-identification problem. On one side are the non-derogable human rights at issue, like the right to be free from arbitrary detention and the prohibition against torture. However, the role that ITCs play in the violations of these rights is probably only indirect. Therefore, although the rights at issue are extremely important, the fact that violations of these rights are not certain until the state takes action may mean that individual rights ultimately fall short when weighed against important corporate interests.

\section{3.iii. BALANCING THE RIGHTS OF ITCS VS RIGHTS OF THE AFFECTED POPUlation}

Now that the substantive rights have been defined in respect to the user-identification problem, the final step of the concentric circle framework requires weighing the rights and interests of the ITCs against the rights of the affected population in order to determine the nature of the obligation on ITCs to respect human rights when confronted with government requests for user-identifying information. According to Ratner's framework, the results of the balancing test, combined with the results of the previous two steps, (defining the strength of the nexus between the ITC and government, and the strength of the nexus between the ITC and the affected people), will determine the extent of the human rights obligations on the ITC.

In terms of the rights and interests of the ITCs, to briefly restate, ITCs as corporations have duties to their shareholders to maximize profits. Unlike states, where protecting human rights are a primary interest, ITCs, like other corporations, are designed to remain competitive by seeking out new business opportunities. Because ITCs are facing the decision to either comply 
with a human rights-abusing regime, or risk having to stop doing business in a lucrative market, ITCs are facing competing duties to shareholders on one side, and to the affected population on the other side.

Obviously, the rights of the affected population in the case of user-identification weigh heavily on one side of the balance. Individuals face the possible loss of liberties and may even face imprisonment and torture when an ITC shares user-identifying information with a repressive government. Such information sharing constitutes a direct violation of the individual's rights to free expression and privacy, which could lead to the indirect human rights violations mentioned above. With so much at stake for individuals, the individual rights weigh heavily in favor of the affected population.

Furthermore, in terms of ITCs' interest in profit maximizing, the negative publicity that accompanies high profile human rights cases like the case of Shi Tao could certainly affect the brand power and profitability of the corporation. ${ }^{195}$ After Yahoo! was derided in United States Congressional hearings, as well as by international human rights organizations, their stock prices fell substantially. ${ }^{196}$ Therefore, in the desire to maximize profits, it may in fact be in the best interest of the ITC to refuse to comply with government demands for information, if by complying they are risking a weakening of their brand power.

As with the censorship problem, no clear "winner" emerges after balancing corporate rights and interests with individual rights and interests. However, the scales in this case do seem to tip slightly in favor of individual rights. First of all, a cyber dissident's rights to free

\footnotetext{
${ }^{195}$ See e.g., D. Vogel, The Market For Virtue: The Potential and Limits of Corporate Social RESPONSIBILITY (2005).

196 "During the two weeks prior to the [congressional hearing concerning Yahoo!'s provision of information to the Chinese government] Yahoo! stock traded consistently in the low $\$ 30$ per share range, but by the end of the day of the 2007 hearing, the price had dropped to $\$ 29.93$. Plaintiff claims that the shares were trading at $\$ 25.79$ by the end of that week and remained in the mid \$20 range through January 2008.” Knopf v. Yahoo! Inc, 2010 WL 965308 (N.D. Cal. Mar. 17, 2010) (order granting defendant's motion to dismiss with leave to amend).
} 
expression and privacy are violated when ITCs share user information. Although there may not be repercussions from these violations unless the state acts, simply sharing the information violates a user's right to anonymously participate in online discourse. Furthermore, the mere possibility that such information could be shared, creates an environment that stifles speech by creating fear in Internet users. ${ }^{197}$ If online users know that their personal information could be shared with authorities, speech will likely be chilled. Therefore, the interest in remaining anonymous online is crucial, whether or not the state takes action to persecute speakers.

In terms of the second group of rights, the interests of the individual also weigh quite heavily. Although the ITC is probably not committing these abuses directly, their actions facilitate abuses that could lead to severe consequences, such as prolonged imprisonment and possibly torture. Furthermore, in the interest of profitability, the ITC may be better served by refusing to comply with government requests, thereby protecting their brand power.

In sum, the individual rights at interest, including the right to privacy and free expression, along with the right to be free from prolonged arbitrary detention and torture, indicate that individual rights seem to outweigh the business rights and interests of ITCs within the framework of the user-identification problem.

\subsection{CONCLUSION TO THE USER-IDENTIFICATION PROBLEM}

By applying Steven Ratner's concentric circles framework for ITC liability facing the user-identification problem, it seems that, again, there is justification for recognizing ITCs as duty bearers of certain human rights obligations.

\footnotetext{
197 See e.g., Michel Foucault, Discipline And Punish: The BIRTh OF THE Prison, 202-03 (2d ed. 1995) (If people know that they might be seen, this possibility alone will restrict their freedom).
} 
In the first step, the strength of the nexus between the ITC and the government was examined. It was found that this nexus is not as strong as it is in the censorship problem. This is due to the fact that there is no unique or special relationship between ITCs and any particular government in terms of the frequency in which ITCs handle government requests for information. In fact, the governments issuing the most data requests are liberal democratic governments, like those of the United States and the United Kingdom. ${ }^{198}$

But, on the other hand, it is also true that there is a special duty ITCs assume by operating in nations known to systematically abuse human rights. This unique duty strengthens the nexus between the ITC and the government. Although the heightened duty on ITCs to protect human rights indicates a stronger nexus between ITCs and certain human rights abusing governments, this factor alone may not be strong enough to indicate a duty on the part of ITCs in the useridentification problem.

This brings us to the second step. In analyzing the nexus between the ITC and the affected population, the nexus is extremely strong-likely strong enough to outweigh the rather weak nexus between the ITC and the government. Due to the sensitive nature of the information passed between ITCs and governments, the nexus with the affected population is particularly strong. As in the case of Shi Tao, the potential consequences for individuals whose rights of free speech and privacy are violated when ITCs share their identifying information with the government are quite serious. Thus, simply the possession of user-identifying information creates quite a strong nexus between ITCs and Internet users seeking to engage in politically subversive speech.

Finally, the third step-identifying the substantive rights and balancing those rights against the rights and interests of the ITC as a corporation — also fails to yield a clear "winner."

\footnotetext{
${ }^{198}$ Ingram, supra note 171.
} 
However, as mentioned above, the scales do tip slightly in favor of the individual rights. This is due to the serious nature of the potential human rights violations, as well as the fact that protecting human rights by refraining from sharing user-identifying information, may be in the best interest of the corporation which seeks to maintain brand power and profitability.

To conclude, the first and the third steps of the concentric circle framework may not be strong indicators that ITCs have human rights obligations within the user-identification problem. However, they both weigh slightly in favor of imposing such obligations. The second step, on the other hand, indicates a strong nexus between the individuals and affected population, thus the results of applying the concentric circle framework to the user-identification problem suggest an obligation on the ITC to protect the human rights of its users. As with the censorship problem, this obligation would likely entail a negative duty on the corporation to refrain from taking any actions that would result in infringements of an individual's right to privacy and expression, except in limited circumstances. 


\section{Chapter 8 \\ CONCLUSION}

Internet services have completely restructured the free speech paradigm and are arguably becoming quasi-public services. The challenges facing Internet companies as they continue to expand their operations around the world are unique within the framework of corporate social responsibility. ITCs provide communication tools, which are becoming more necessary than ever, in order for individuals to participate in the public discourse. It seems hardly worth noting that the use of email and other web-based communication tools will only continue to proliferate in the coming decades.

As Internet companies are gaining more control over how the rights to free speech and expression are exercised, it is crucial that standards for corporate responsibility be considered to govern the actions of Internet companies when they extend their operations to nations seeking to restrict rights to free speech and expression. Even Richard Posner, known for his theories on law and economics, and a corporate liability skeptic, argues in favor of placing obligations on ITCs to respect human rights. He writes, for "companies actively to assist a foreign, repressive regime to persecute its political and religious dissidents is a step beyond." 199

This necessity has also been noted by many ITCs who have voluntarily signed on to the Global Network Initiative, which notes that ITCs "have the responsibility to respect and protect the freedom of expression and privacy rights of their users. [The Internet] has the potential to enable the exchange of ideas and access to information in a way that supports economic opportunity, advances knowledge and improves quality of life."200 Such soft law instruments,

\footnotetext{
${ }^{199}$ Posting of R. Posner to Becker-Posner Blog, Google in China, (Feb. 26, 2006), http://www.becker-posnerblog.com/archives/2006/02/ (last visited March 29, 2011).

${ }^{200}$ Global Network Initiative, Principles (2008), http://www.globalnetworkinitiative.org/principles/index.php, (last visited March 31, 2011).
} 
while non-binding, indicate at least some degree of willingness on the part of Internet companies, to abide by international human rights laws. ${ }^{201}$

This paper has discussed how Ratner's concentric circles framework for corporate social responsibility may be applied to ITCs who do business in repressive regimes. After applying the framework to the censorship problem and to the user-identification problem, this analysis has shown that perhaps there is a justification for beginning to extend certain human rights obligations to ITCs. Close ties between ITCs and the governments where they do business, as well as the ties between ITCs and their users, who receive their services directly and not through an intermediary, may justify an obligation on the part of ITCs to respect the human rights of individuals affected by censorship and government requests for information. Again, due to the fact that corporate responsibility is still very much in the developmental stages, such an obligation would likely only include a limited negative duty — a duty to refrain from taking actions that inhibit a user's right to use the Internet to engage in political discourse.

Many of the ITCs, who agree to censor content, actively and independently engage in such censorship in order to ensure that their license to operate in a country like China is reinstated for the following year. These sorts of actions seem to be clear violations of the human rights to free speech and expression. However, because the right to free speech is not absolute, and is subject to different restrictions in different nations, attempting to impose a standard on ITCs as to what sort of censorship is permissible is quite difficult. Likewise, refusing to comply with an official government request could violate domestic law and compromise the ITC's ability to do business in a certain country. And perhaps, by removing its business from an

\footnotetext{
${ }^{201}$ But see M. Buetz Land, supra note 155, noting criticism of such soft-law instruments. ("[T]here is a risk that superficial compliance with the principles might provide cover to companies seeking to do business in restrictive regimes. Second, the principles' ambiguity means that companies have to exercise judgment and imagination in responding to demands to follow local law. Third, there may be few incentives for companies to engage with local governments or to invest the resources needed to achieve long-term change.").
} 
Internet-restricting country, the ITC has disregarded the public interest in having multiple options for Internet service, thereby broadening the Internet user-base.

These competing interests make setting standards to extend human rights duties to ITCs extremely difficult. However, by seeking to only impose negative duties on ITCs-which could require that ITCs refrain from actively engaging in censorship of political speech, and refuse to provide governments with user-identifying information when it is likely to be used by the state to engage in human rights violations — beginning to set such standards may be feasible. 